Geotechnical Engineering Research Program

Installation of Fiber-Optic Cables Under Flood-Protection Structures Using Horizontal Directional Drilling Techniques

Patrick J. Conroy, Carlos A. Latorre,

May 2002 and Lillian D. Wakeley

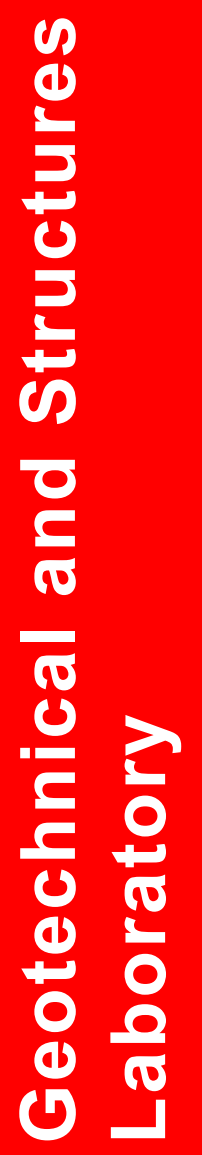


The contents of this report are not to be used for advertising, publication, or promotional purposes. Citation of trade names does not constitute an official endorsement or approval of the use of such commercial products.

The findings of this report are not to be construed as an official Department of the Army position, unless so designated by other authorized documents. 


\section{Installation of Fiber-Optic Cables Under Flood-Protection Structures Using Horizontal Directional Drilling Techniques}

by Patrick J. Conroy

U.S. Army Engineer District, St. Louis

1222 Spruce Street

St. Louis, MO 63103-2833

Carlos A. Latorre, Lillian D. Wakeley

Geotechnical and Structures Laboratory

U.S. Army Engineer Research and Development Center 3909 Halls Ferry Road

Vicksburg, MS 39180-6199

Final report

Approved for public release; distribution is unlimited 


\section{Contents}

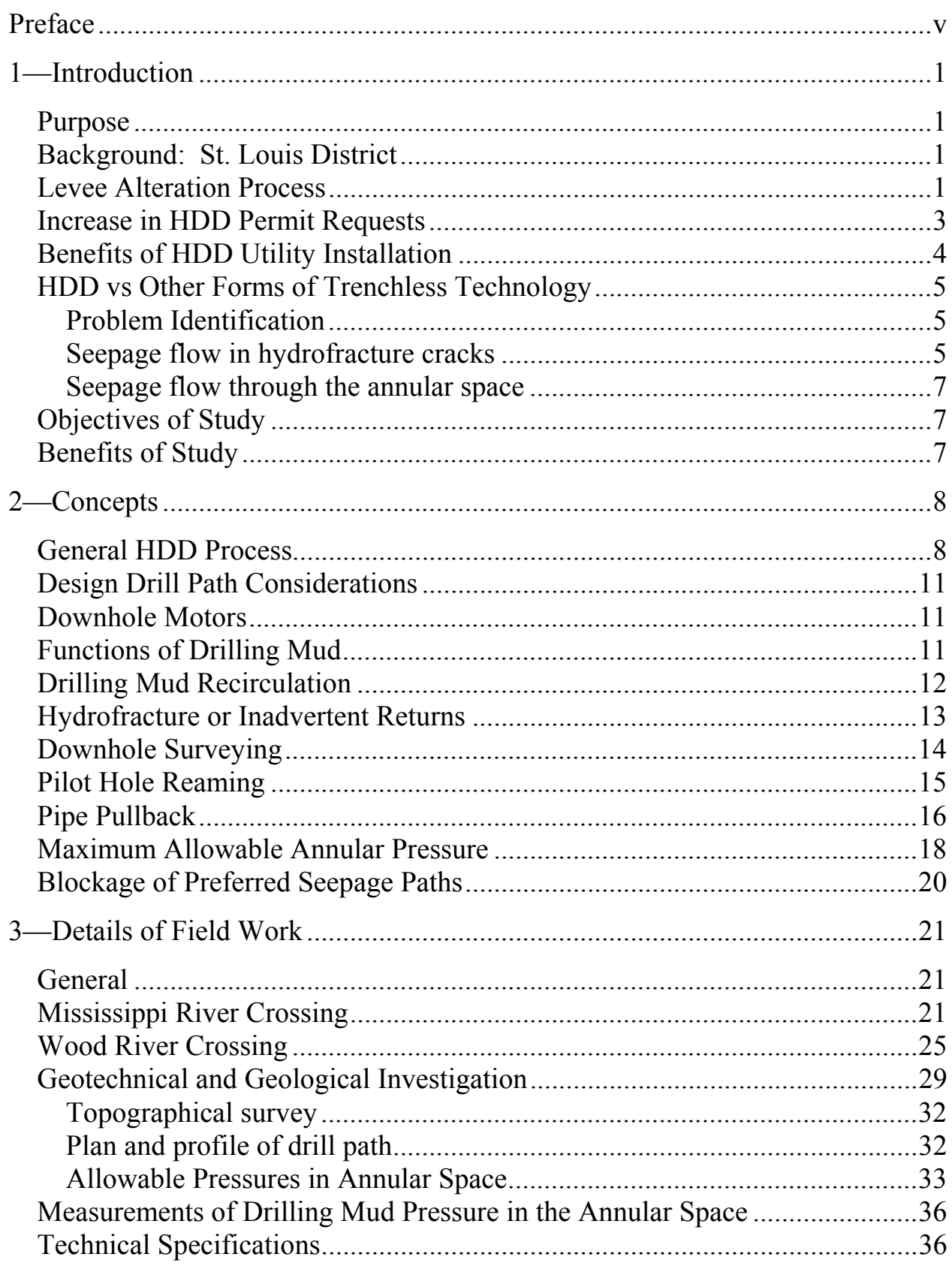




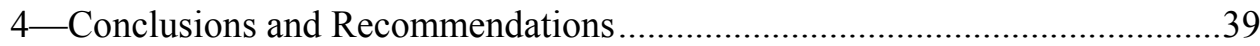

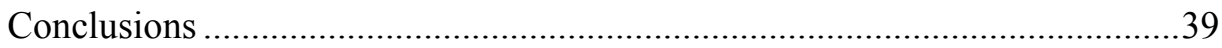

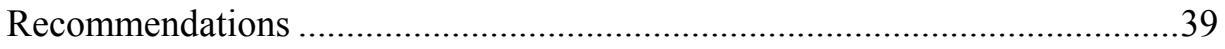

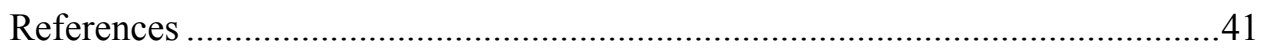

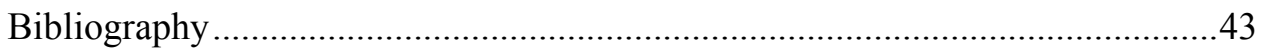

Appendix A: American Fiber Comm Mississippi River Bore Special

Conditions

SF 298

\section{List of Figures}

Figure 1. Map of USAED, St. Louis ......................................................... 2

Figure 2. Generalized stratigraphy and seepage regime............................. 6

Figure 3. Schematic of drill path ......................................................... 10

Figure 4. Typical bottom hole assembly .............................................. 10

Figure 5. Drilling mud recycling system................................................ 13

Figure 6. Typical spoil .................................................................... 14

Figure 7. Schematic of surface monitoring .......................................... 16

Figure 8. Typical reaming tools ............................................................ 17

Figure 9. Pipe pullback ................................................................. 18

Figure 10. Regional view of Mississippi River bore................................... 22

Figure 11. Missouri side plan view ........................................................ 23

Figure 12. Illinois side plan view .......................................................... 23

Figure 13. Bore profile under Missouri side ............................................ 24

Figure 14. Bore profile under Illinois shore ............................................. 24

Figure 15. Regional view of Cahokia Creek Crossing ................................. 26

Figure 16. Plan view of Cahokia Creek Crossing ....................................... 27

Figure 17. Profile view of Cahokia Creek Crossing .................................... 28

Figure 18. Mississippi River Crossing boring logs ................................... 30

Figure 19. Cahokia Creek Crossing boring logs ....................................... 31

Figure 20. Williams Communications drilling pressures during HDD ......... 37

Figure 21. American Fiber Comm drilling pressures during HDD .............. 38 


\section{Preface}

This study was conducted and the report was written during 1999 and 2000 by Mr. Patrick J. Conroy, P.E., Geotechnical Branch, Engineering Division, U.S. Army Engineer District (USAED), St. Louis (MVS), St. Louis, MO; and Mr. Carlos Latorre, P.G., Engineering Geology and Geophysics Branch (EGGB), and Dr. Lillian D. Wakeley, P.G., Chief, EGGB, Geosciences and Structures Division (GSD), Geotechnical and Structures Laboratory (GSL), U.S. Army Engineer Research and Development Center (ERDC), Vicksburg, MS. Funding for preparation and publication of this report was provided by the U.S. Army Corps of Engineers as part of its ongoing support of civil works research through the Geotechnical Engineering Research Program (GTERP). Dr. Wakeley is GTERP Manager, and Mr. Jim Chang, CECW, is GTERP Technical Monitor.

Field activities described in this report were planned and conducted under the general supervision of Mr. George Postol, Chief, Geotechnical Branch, USAED, St. Louis. The ERDC and St. Louis' cooperative efforts to prepare this report were initiated and supervised by Dr. Wakeley. General supervision of the project was provided by Dr. Robert L. Hall, Chief, GSD, and Dr. David W. Pittman, Acting Director, GSL. Messrs. Chang, George Sills, CEMVK-ED-G, Peter Cali, CEMVO, and John Wise, CESWF-ED-DG, provided independent technical reviews of the report.

The people of the ERDC, GSL, and CEMVS acknowledge the enthusiastic teamwork demonstrated through this cooperative effort. Special acknowledgement is made to the earlier work on horizontal directional drilling conducted by Dr. R. David Bennett, former GTERP Manager, and by Ms. Kimberlie Staheli, formerly GSL, ERDC.

American Fiber Comm, Edwardsville, IL, and Sheppard, Morgan, and Schwabb, Inc., Consulting Engineers, Alton, IL, provided written permission to reprint "Mississippi River Bore Special Condition" as Appendix A.

At the time of publication of this report, Dr. James R. Houston was Director of ERDC. COL John W. Morris III, EN, was ERDC Commander and Executive Director.

The contents of this report are not to be used for advertising, publication, or promotional purposes. Citation of trade names does not constitute an official endorsement or approval of the use of such commercial products. 


\section{Introduction}

\section{Purpose}

Rapid increases in Internet usage in the United States have created a massive expansion of the infrastructure of digital communications. In response to the Telecommunications Act of 1996, the communications industry has installed many thousands of kilometers (miles) of fiber-optic cables to support these communications. A large percentage of these have been installed underground using Horizontal Directional Drilling (HDD) techniques. The natural gas and electrical power industries and the American Public Works Association have embraced HDD as a viable method for their infrastructure installation. As HDD techniques have improved in the last 5 years and use of these techniques has expanded throughout the construction industry, interest in using HDD for installing subsurface communications cables has likewise increased. This paper describes the experience of the U.S. Army Engineer District (USAED), St. Louis, (hereafter called the District) with installation of fiber-optic cables under U.S. Army Corps of Engineers (USACE) levees using HDD techniques.

\section{Background: St. Louis District}

The USAED, St. Louis, lies in the country's heartland, strategically located on the Mississippi River near its confluence with the Illinois and Missouri Rivers (Figure 1). District boundaries include about $483 \mathrm{~km}$ (300 miles) of the Upper Mississippi River, $99.8 \mathrm{~km}$ (62 miles) of the lower Missouri River, $128 \mathrm{~km}$ (80 miles) of the lower Illinois River, and all of the Salt, Meramec, Kaskaskia, and Big Muddy Rivers. The District is responsible for five navigation locks and dams on the Mississippi and Kaskaskia Rivers; five combination flood control/ recreation reservoirs on the Kaskaskia, Salt, and St. Francis Rivers; and numerous flood control projects throughout the District.

\section{Levee Alteration Process}

The flood-control projects within the District boundaries include Federal and Non-Federal projects providing protection from floods varying in magnitude 


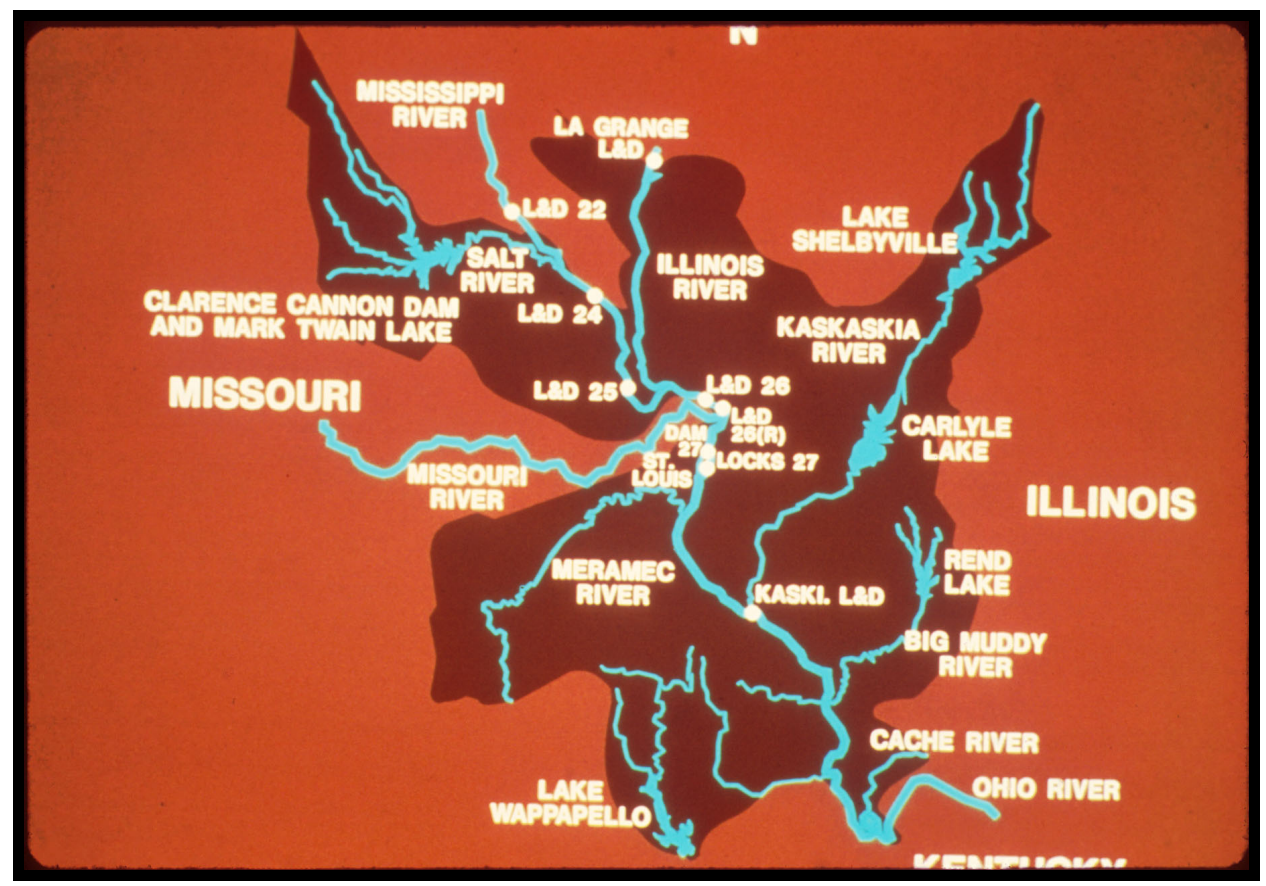

Figure 1. Map of USAED, St. Louis

from the 20- to 500-yr occurrence interval. Within the District, Federal projects are completely under USACE control and the District provides all operations and maintenance efforts. Non-Federal levees are controlled by the local levee districts, which are political entities responsible for operating and maintaining the flood-control projects within their district. The District works closely with the local levee districts within its boundaries to ensure that all flood-protection projects are properly maintained.

With continued economic growth and on an as-needed basis, third parties outside of the USACE and the local levee districts request permission to alter some aspect of an existing flood-control project to accommodate new development. This new development has taken many different shapes, from construction of bike paths on the levee crown to levee realignment to accommodate a new state highway. Other alterations include new road ramps that cross the levee or construction of bulk commodity loading/unloading facilities riverside of the levee to support multimodal transportation hubs. Many times the third party wishes to construct a simple utility line across the levee.

The standard procedure in such an alteration is that the third party submits its request along with detailed plans and drawings to the local levee district. The levee district will forward these to the St. Louis District for review. The District will reply to the local levee district recommending approval or disapproval of the proposed alteration. Disapproval is accompanied by comments that must be resolved to approve the alteration request. 


\section{Increase in HDD Permit Requests}

Until 1998, the majority of requested utility-line crossings were surface crossings built up and over the existing levee section according to standard details developed by the St. Louis District. This standard included a 0.6-m (2-ft) minimum earthen cover over the utility pipe. Although the total number of requests had been very small, any requests to directionally drill under floodprotection projects were disapproved. At that time, the District was reluctant to use HDD techniques to install utilities under any flood-protection levees.

Although information about the procedures was readily available from equipment manufacturers and contractors, there was only a minimal experience base and no standard procedures for using HDD under USACE levees. Because the Corps maintains Federal responsibility for flood protection, the District was concerned that drilling under levees could create preferred seepage paths that could lead to the formation of landside sand boils and result in potentially dangerous conditions during a flood. In addition, there were discussions within the USACE concerning unfavorable experiences with HDD, where levee damage was caused by pressure-fracturing of the upper layers of geologic material (top stratum) during the directional drilling process.

In 1998, possibly in response to the opportunities provided by the 1996 Telecommunications Act, the number of requests from private firms to use HDD to build fiber-optic-cable crossings under levees increased substantially. The District embarked on an effort to learn about HDD and determine if process controls could be specified so that the drilling could be done below flood protection projects without damaging them. Using information published by the U.S. Army Engineer Research and Development Center (ERDC) (formerly the Waterways Experiment Station), experiences of other Corps Districts, and information available from directional drill manufacturers, drilling contractors, HDD societies, and private engineering firms, the District developed methods and processes that protect the integrity of a flood-control project during directional drilling. The methods and processes are intended to prevent the occurrence of hydrofracture during installation and to prevent development of preferred seepage paths along the crossing, thus protecting levee integrity and maintaining flood-control capability.

These methodologies and processes have been imposed on third parties who have requested permission to install utilities under flood protection projects using HDD techniques. To date, there have been six levee alterations completed within the District boundaries that include utility installation under a local levee using HDD techniques. Table 1 lists the levee districts and associated river, the owner, driller, length, and diameter of these installations. In these instances, when the District received the review package from the local levee district, the utility owner was contacted and a dialogue was initiated that resulted in a close working relationship between the levee district, the utility owner, and the engineer. At construction, the District developed good working relations with the drilling company and maintained close contact during the installation process. The results of two of these projects will be presented in detail. 


\begin{tabular}{|c|c|c|c|c|c|}
\hline \multicolumn{6}{|c|}{$\begin{array}{l}\text { Table } 1 \\
\text { Fiber-Optic-Cable Installation }\end{array}$} \\
\hline Levee District & $\begin{array}{l}\begin{array}{l}\text { Adjacent to } \\
\text { this River }\end{array} \\
\end{array}$ & Owner & Driller & $\begin{array}{l}\text { Length } \\
\mathrm{m}(\mathrm{ft})\end{array}$ & $\begin{array}{l}\text { Pipe Diam } \\
\text { cm (in.) }\end{array}$ \\
\hline "Valley Park & Meramec & Level3 & $\begin{array}{l}\text { Cherrington } \\
\text { Corp }\end{array}$ & $461(1,513)$ & $30.5(12)$ \\
\hline $\begin{array}{l}\text { St. Louis and } \\
\text { MESD }\end{array}$ & Mississippi & Level3 & $\begin{array}{l}\text { Cherrington } \\
\text { Corp }\end{array}$ & $761(2,498)$ & $30.5(12)$ \\
\hline Wood River & Wood River & Level3 & InterCon & $594(1,950)$ & $30.5(12)$ \\
\hline $\begin{array}{l}\text { MESD and } \\
\text { Wood River }{ }^{1}\end{array}$ & $\begin{array}{l}\text { Cahokia } \\
\text { Diversion }\end{array}$ & Williams & Mears/HDD & $847(2,778)$ & $10.2(4)$ \\
\hline St. Louis & Mississippi & $\begin{array}{l}\text { American } \\
\text { Fiber Comm }\end{array}$ & $\begin{array}{l}\text { Tom Allen } \\
\text { Const. }\end{array}$ & $824(2,706)$ & $26.4(10.375)$ \\
\hline $\begin{array}{l}\text { St. Louis and } \\
\text { MESD }^{1}\end{array}$ & Mississippi & $\begin{array}{l}\text { American } \\
\text { Fiber Comm }\end{array}$ & $\begin{array}{l}\text { Tom Allen } \\
\text { Const. }\end{array}$ & $1,314(4,310)$ & $25.4(10)$ \\
\hline
\end{tabular}

\section{Benefits of HDD Utility Installation}

Although typically more expensive than other types of installation, underground installations provide more protection to the utility. When the utility includes fiber-optic cables, the owner wishes to provide the best protection to the commodity (data) flowing in the cables. The installations shown in Table 1 typically included the installation of three or four fiber-optic cables in the casing, and each of these fiber-optic cables contain over 100 separate glass strands. With modern digital compression schemes, each strand is capable of carrying thousands of simultaneous phone calls. The installed utilities in Table 1 represent a large capital investment in digital information capability. The owners desire to protect this investment and deep underground installations provide the best protection.

At river crossings, a surface installation includes excavating a trench across the river bottom, laying the utility in the trench bottom and then backfilling the trench. In this installation, the trench backfill is subject to the erosive forces of the flowing water, and in the worst case, the buried utility pipeline can be exposed. At this point, the uncovered utility is subject to damage from debrisladen flows in the river. Utility crossings installed with HDD are typically deep enough to escape the threat of erosion.

Construction efforts associated with new development can threaten surface utility installations. The occurrences of cables being severed by errant excavations are well documented and, unfortunately, occur with alarming frequency. Utility crossings installed with HDD are typically deep enough that many excavations do not come near the underground cable.

The States of Missouri and Illinois have begun to prohibit utility connections on their bridges. Since the opportunity for this type of river crossing may be disappearing, another type must take its place and HDD adequately fills the gap. 


\section{HDD vs Other Forms of Trenchless Technology}

Other forms of trenchless technology are available for utility installation including minidirectional drilling, microtunneling, and pipe ramming.

Minidirectional drilling is generally limited to $25.4-\mathrm{cm}$ (10-in.) diameter bores and maximum $183-\mathrm{m}(600-\mathrm{ft})$ lengths. By inspection of the dimensions in Table 1, it is obvious that minidirectional drilling does not have the capability for these jobs. Minidirectional drilling may be appropriate for smaller jobs.

Pipe ramming uses a horizontally oriented hammer that imparts energy into the pipe to drive it through the soil. The process may disturb the surrounding soils and using this method to install a pipe under a levee embankment could damage the levee. Pipe ramming cannot make the necessary turns and grade changes to negotiate obstacles. Pipe ramming does not appear to be a viable method for installing pipelines under levee.

Microtunneling has been used to install pipes from $25.4 \mathrm{~cm}$ (10 in.) to $3.05 \mathrm{~m}$ $(10 \mathrm{ft})$ in diameter using auger or slurry-based spoil removal systems. But microtunneling is more expensive than HDD.

In the cases shown in Table 1, HDD remains the desired system because of its ability to install pipes of 10.2 to $30.5 \mathrm{~cm}$ (4 to $12 \mathrm{in}$.) in diameter in soils and soft rock over great lengths with changing grades and alignment.

\section{Problem Identification}

The levee districts within the St. Louis District, protect rural and urban areas. During the 1993 flood on the Mississippi and Missouri Rivers, the Public Affairs Office of the District estimates that these levees prevented $\$ 5.3$ billion of flood damage. While considering any alteration request, the District's prime objective is to protect the integrity of these flood protection systems. In the case of HDD, the District is concerned with these problems:

a. Possible hydrofracture and subsequent damage to the landside blanket during the pipeline installation.

$b$. Preferred seepage paths in the annular space between the pipeline and the borehole wall.

To allow third parties to utilize HDD techniques, the District needed methods and processes to prevent these problems from occurring.

\section{Seepage flow in hydrofracture cracks}

The typical stratigraphy in the District consists of a surficial blanket of finegrained soils ( 0 to $6 \mathrm{~m}$ ( 0 to $20 \mathrm{ft}$ ) thick) overlying a coarse-grained aquifer that is 9 to $30 \mathrm{~m} \mathrm{(30} \mathrm{to} 100 \mathrm{ft}$ ) thick. These unconsolidated soils are underlain by 
bedrock. During floods, the coarse-grained aquifer becomes confined and artesian pressures build up in the aquifer and act upward on the base of the finegrained blanket landside of the levee. Figure 2 shows the generalized stratigraphy and seepage flow regime. Depending on many factors including the thicknesses and permeabilities of the blanket and aquifer, the distance from the levee to the channel and the duration of the flood, these excess water pressures may create upward seepage gradients and subsequent seepage. If the gradients exceed the critical value for the landside blanket, sand boils will initiate. If left uncontrolled, a sand boil can grow and ultimately threaten the levee integrity.

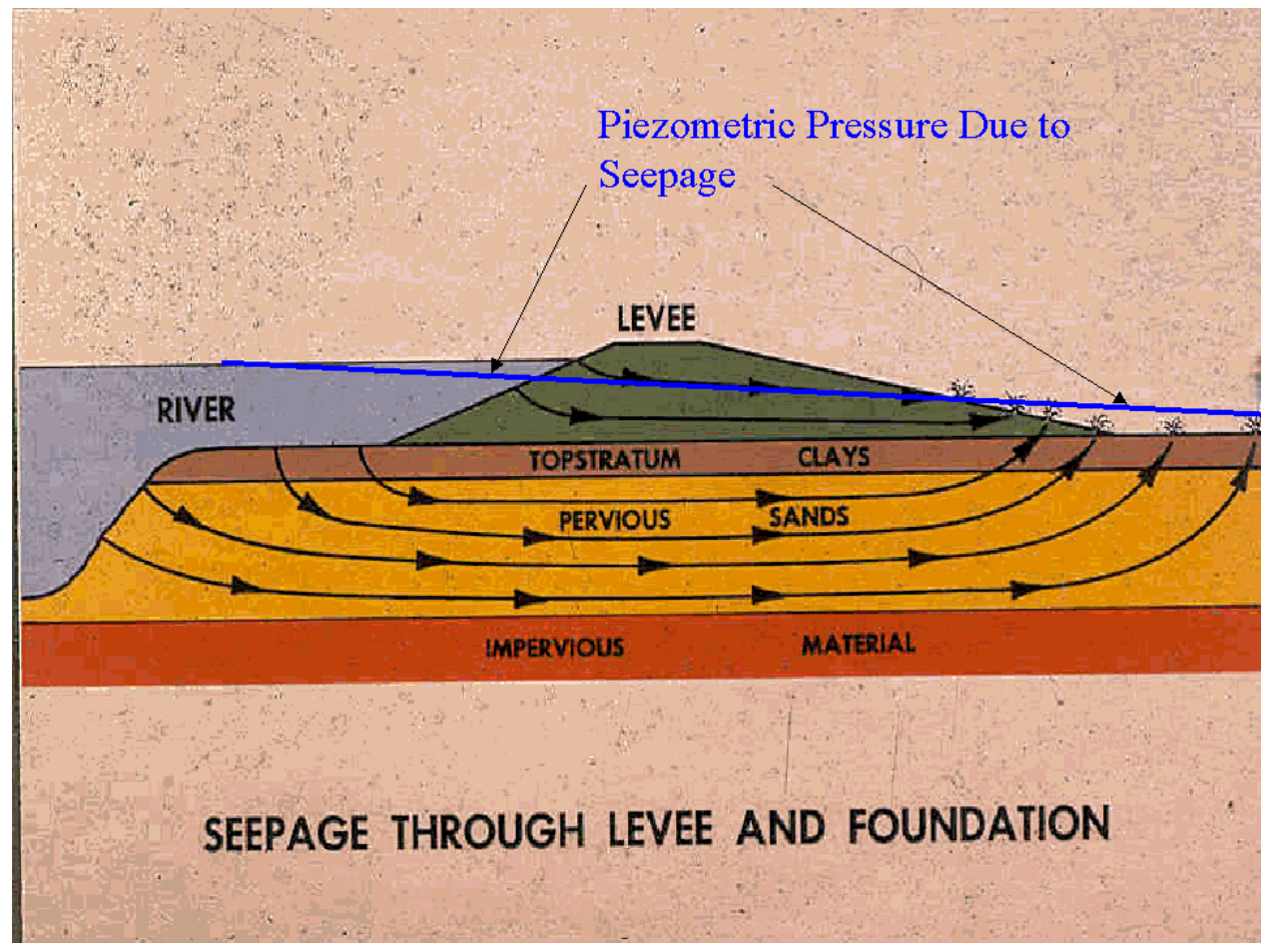

Figure 2. Generalized stratigraphy and seepage regime

The landside surficial blanket is the first line of defense against seepage flows, and any defect in this blanket will exacerbate the seepage phenomena described above. Natural defects in the fine-grained blanket such as sand lenses, thin spots in the blanket, or animal burrows will experience greater gradients and seepage rates during a flood. Manmade items such as fence posts, basements, signposts or excavations can cause seepage concentrations and higher seepage gradients in the vicinity of the manmade item during a flood. When using HDD techniques under levees, a crack in the landside blanket created by hydrofracture during the drilling operation will cause higher gradients and seepage flow rates in that vicinity during a flood. The District needed to find a way to monitor the drilling process to prevent hydrofracture. 


\section{Seepage flow through the annular space}

Typically, the diameter of the borehole is larger than the diameter of the pipe to be installed. The radius of the borehole can be 1.25 to 1.5 times as large as the radius of the pipe. If nothing is done to block the annular space between the installed pipe and the borehole wall, this space will provide an easy route for seepage water to flow from the underlying aquifer, through the landside blanket to the surface during a flood. The District needed to develop a way to block this annular space.

\section{Objectives of Study}

The prime objective of this study was to develop methods and processes for using HDD techniques to install pipes and conduits under Corps flood protection projects without compromising its integrity. To do this, the District needed to find a way to monitor and control the drilling process to prevent hydrofracture and to determine a way to block the annular space between the conduit and the borehole to prevent seepage flows.

The secondary objectives were to use emerging technology to predict and measure the pressures involved in hydrofracture and to develop contract documents that would more effectively control the drilling contractor without becoming burdensome.

\section{Benefits of Study}

The results of this study could conceivably benefit the Corps and the industry. The Corps gets to learn more about HDD and is actively involved in the technology. The Corps may be able to influence the direction that the directional drilling industry takes in the future. Owners get to install their infrastructure in a manner that protects their investment. 


\section{Concepts}

\section{General HDD Process}

Selection of HDD for use on a particular crossing should be predicated on a thorough understanding of the site's characteristics. If HDD is the selected construction method, the site's natural and man-made features should govern the crossing design. For a pipeline to be installed by HDD, either an open hole must be cut into the subsurface material so that a pipeline can be pulled back through it, or the soil properties must be modified so that a pipeline can be pulled back through it. While the length and diameter of the borehole impact the feasibility of an HDD installation, the properties of the subsurface materials control the situation. Table 2 describes various subsurface conditions and the feasibility of using HDD techniques in that soil.

A designed drilled path for the borehole consists of a series of straight lines and curves. The location and configuration of a drilled profile are defined by its entry and exit points, entry and exit angles, radius of curvature, and points of curvature and tangency. The interrelationship of these parameters is shown in Figure 3.

The process consists of drilling a guided pilot bore, generally using a 7.3- to 15.2-cm (2-7/8- to 6-in.)-diam drill pipe and a slightly larger-diameter cutting tool. At the downhole end of the drill string is a drilling mud-powered cutting tool. The cutting tool consists of a mud motor to which a drill bit is attached or a simple jetting tool. Drilling mud is pumped into the drill string at the drilling rig at high pressure. If a mud motor and drill bit are used, the drilling mud causes the mud motor to rotate which, in turn, rotates the drill bit and cuts the hole. If a jetting tool is used, the drilling mud exits the orifices in the jetting tool and erodes the hole in front of the jetting tool.

In some installations, the drilling mud flows back to the surface in the annular space between the drill string and the wall of the pilot hole. In this case, the return flow removes the cuttings from the drilling bit and flushes them back to the surface. In other installations, no return flow is desired. Just enough drilling fluid is mixed with the cuttings to create slurry that remains in the hole, thereby stabilizing it. 


\begin{tabular}{|c|c|c|}
\hline \multicolumn{3}{|c|}{$\begin{array}{l}\text { Table } 2 \\
\text { Feasibility of Using HDD in Various Soils }{ }^{1}\end{array}$} \\
\hline Earth Material Type & $\begin{array}{l}\text { Gravel \% } \\
\text { by Weight }\end{array}$ & HDD Feasibility \\
\hline $\begin{array}{l}\text { Very soft to hard strength, } \\
\text { possibly slickensided, } \\
\text { clay. }\end{array}$ & N/A & $\begin{array}{l}\text { Good to Excellent. Plugging of the annulus } \\
\text { surrounding the drill stem during pilot hole drilling may } \\
\text { produce inadvertent drilling fluid returns through } \\
\text { slickensides or hydrofractures. Penetration of strong } \\
\text { clay surrounded by considerably weaker or looser soils } \\
\text { may result in the pilot bit "skipping" along the interface. } \\
\text { Pilot hole steering difficulties are likely to result during } \\
\text { passage through very soft layers. }\end{array}$ \\
\hline $\begin{array}{l}\text { Very loose to very dense } \\
\text { sand with or w/o gravel. }\end{array}$ & 0 to 30 & $\begin{array}{l}\text { Good to Excellent. Gravel may cause slight steering } \\
\text { problems. Some steering imprecision may also result } \\
\text { during passage through very loose material. }\end{array}$ \\
\hline $\begin{array}{l}\text { Very loose to very dense } \\
\text { gravelly sand }\end{array}$ & 30 to 50 & $\begin{array}{l}\text { Marginally Acceptable. Drilling mud characteristics and } \\
\text { handling are critical to success. Pilot hole steering } \\
\text { may be imprecise. }\end{array}$ \\
\hline $\begin{array}{l}\text { Very loose to very dense } \\
\text { sandy gravel }\end{array}$ & 50 to 85 & $\begin{array}{l}\text { Questionable. Horizontal penetration for any } \\
\text { substantial distance will be extremely difficult } \\
\text { regardless of drilling fluid quality. Pilot hole steering } \\
\text { may be imprecise. }\end{array}$ \\
\hline $\begin{array}{l}\text { Very loose to very dense } \\
\text { gravel }\end{array}$ & 85 to 100 & $\begin{array}{l}\text { Unacceptable. With present technology and } \\
\text { experience, horizontal penetration, especially in the } \\
\text { denser strata, is almost impossible. Such materials } \\
\text { must be avoided or penetrated at a steep angle. }\end{array}$ \\
\hline Rock & & $\begin{array}{l}\text { Excellent to Unacceptable. Softer or partially } \\
\text { weathered materials offer HDD performance akin to } \\
\text { that of hard strength clay. Technology is available to } \\
\text { drill through more competent rock, especially in the } \\
\text { weaker horizontal plane. Penetrating solid rock after } \\
\text { passing through soil may be difficult due to the bit's } \\
\text { tendency to "skip" along the lower hard surface. If in } \\
\text { "rounded" cobble form, competent rock is virtually } \\
\text { impossible to drill. }\end{array}$ \\
\hline
\end{tabular}

Located behind the drilling head is a section of drill pipe with a small bend or angular deviation, known as a bent sub or bent housing, that allows the drilling bit or jetting tool to be directed. Also located behind the drilling head is an electronic survey probe that can determine the azimuth, inclination, and orientation of the drilling bit or jetting tool. This package provides the basic information that is analyzed to determine the drilling progress and path.

Upon completion of the pilot hole, the drill bit is removed and, if necessary, a reaming tool is attached and pulled back through the pilot hole to enlarge it. Once the borehole is enlarged to the desired diameter, the pipeline or conduit is attached to the drill pipe and pulled back through the borehole.

The combination of drill string, mud motor (if used), bent subs, electronic survey probe, and drill bit or jetting tool is referred to as the Bottom Hole Assembly. A typical Bottom Hole Assembly is shown as Figure 4. 


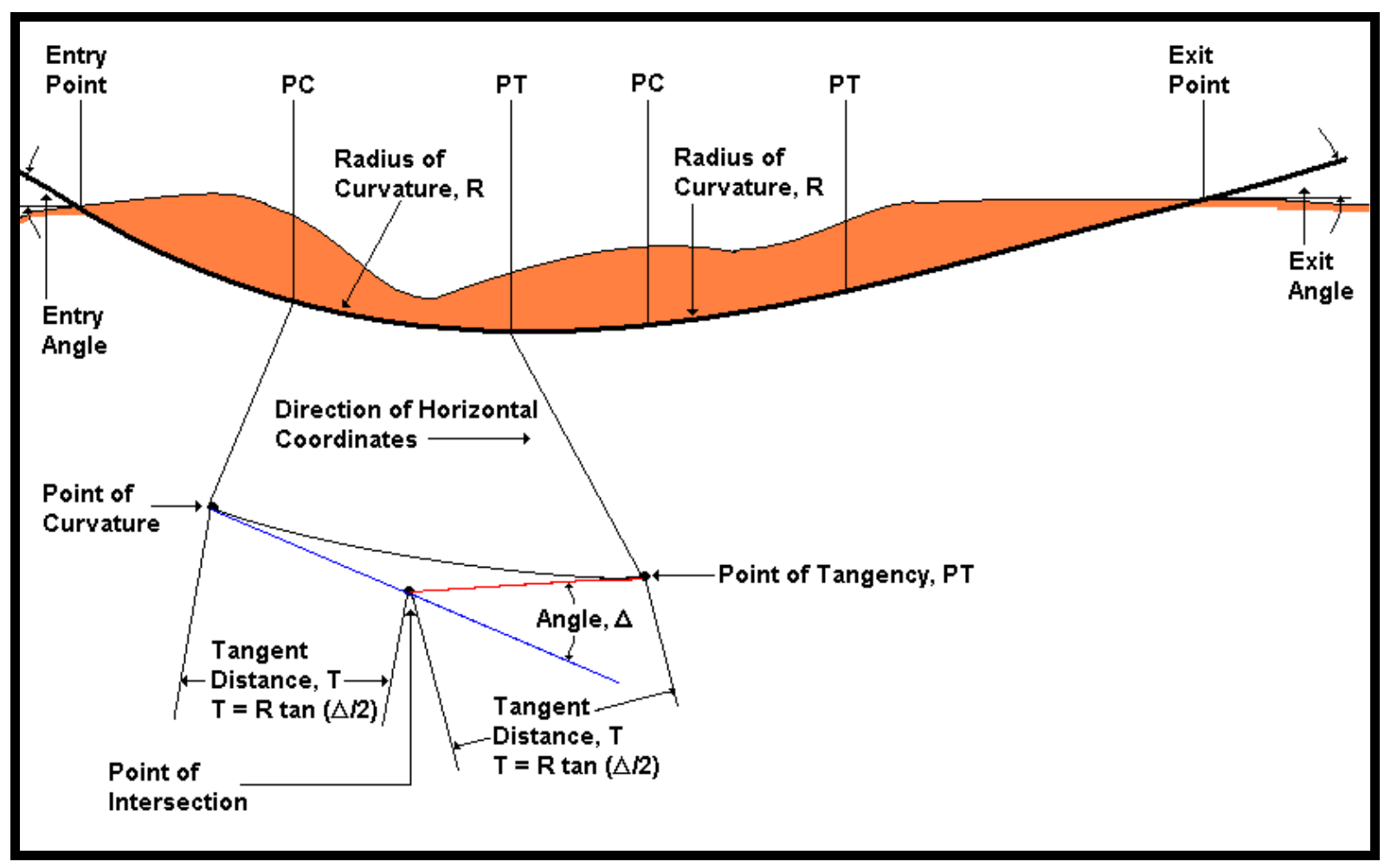

Figure 3. Schematic of drill path

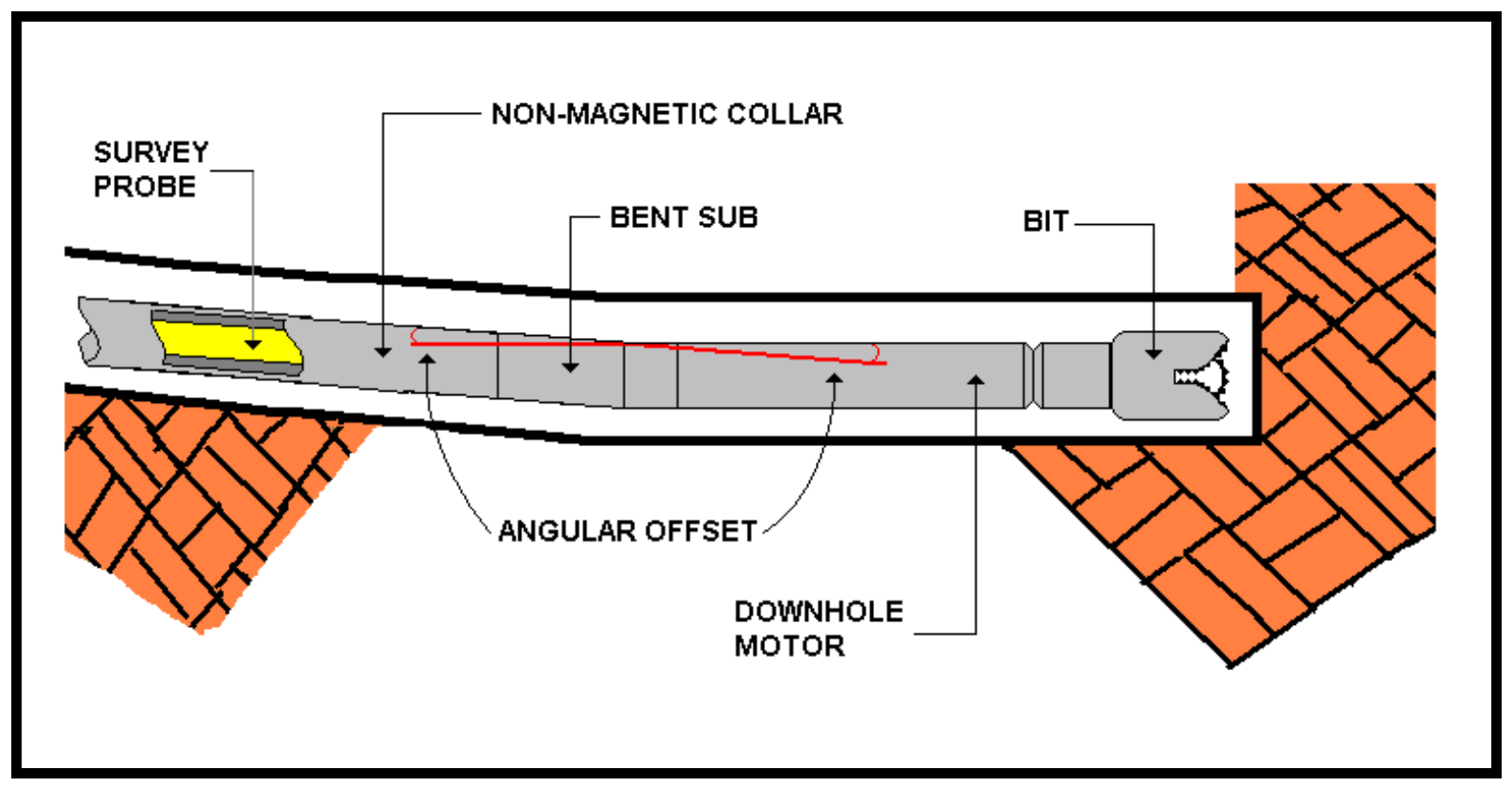

Figure 4. Typical bottom hole assembly 


\section{Design Drill Path Considerations}

The drill path consists of simple curves and straight segments. The curves are generally defined as simple circular curves using standard surveying relationships. Nomenclature is shown in Figure 3. The entry and exit points are the end points of the drilled profile with the drilling rig positioned at the entry point. The pipeline is pulled into the exit point and back to the entry point. The relative location of the entry and exit points, and consequently, the direction of pilot hole drilling, reaming, and pulling back, should be established by the site's geotechnical, geological, and topographical conditions. When choosing the relative locations of the entry and exit points, it is important to note that steering precision and drilling effectiveness are greater close to the drilling rig. Where possible, the entry point should be located closest to anticipated adverse subsurface conditions.

An additional consideration is the availability of workspace for pull section fabrication. It is preferable to have workspace in line with the drilled segment and extending back from the exit point the length of the pull section plus $61 \mathrm{~m}$ $(200 \mathrm{ft})$. This will allow the pull section to be prefabricated in one continuous length prior to installation. If space is not available, the pull section may be fabricated in two or more sections that are welded together during installation. However, welding during installation slows the pullback process and increases the chances of getting the pipe stuck.

Because of equipment limitations, entry angles should be held between 8 and $20 \mathrm{deg}$ with horizontal. Horizontal drilling rigs are typically manufactured to operate at 10 to $12 \mathrm{deg}$. Exit angles should be designed to allow easy breakover support; that is, the exit angle should not be so steep that the pipeline must be severely elevated to guide it into the drilled hole.

\section{Downhole Motors}

Downhole hydraulic motors, commonly referred to as mud motors, provide the mechanical cutting action required for harder soils. The mud motor converts the hydraulic energy contained in the drilling mud to mechanical energy at the bit allowing for bit rotation without drill string rotation. Positive displacement mud motors are typically used in HDD applications. A positive displacement mud motor consists of a spiral-shaped stator containing a sinusoidal shaped rotor. Mudflow through the stator imparts rotation to the rotor and the drill bit.

\section{Functions of Drilling Mud}

The principal functions of drilling fluid in HDD pipeline installation are listed on the following page. 
a. Transportation of spoil. Excavated soil or rock cuttings are suspended in the fluid and carried to the surface by the fluid stream flowing in the annulus between the hole and the pipe.

b. Cooling and cleaning of cutters. The drill fluid cools the drill tool and removes spoil buildup on the cutting teeth.

c. Reduction of friction. The lubricating properties of the drill mud reduce friction between the pipe and the borehole wall.

d. Hole stabilization. The drilling fluid stabilizes the pilot hole or reamed hole. This is critical in uncased HDD installations in soft soil formations. Stabilization is accomplished when the drilling fluid builds up a cake on the borehole wall and exerts a positive pressure on the borehole wall.

e. Transmission of hydraulic power. Power required to turn the bit and mechanically drill a hole is transmitted to a downhole motor by the drilling fluid.

f. Hydraulic excavation. Soil is excavated by erosion from high-velocity fluid streams directed from jet nozzles on bits or reaming tools.

g. Soil modification. In some installations, no return flow is desired. Enough drill mud is introduced into the hole to mix with the soil along the drilled path. This facilitates installation of the pipeline by reducing the shear strength of the soil to a near fluid condition. The resulting soil mixture is displaced as the pipeline is pulled back.

\section{Drilling Mud Recirculation}

Horizontal directional drilling installations that utilize a drilling mud return flow generate large volumes of drilling mud that must be dealt with. The first step in effectively dealing with excess drilling fluid disposal is to eliminate, or minimize, the excess. This is accomplished by recirculating drilling fluid returns to the extent practical. Collected surface returns should be processed through a recycling system that mechanically separates the spoil from drilling fluid, allowing the fluid to be reused. The components of a typical mechanical separation system are listed below.

a. Coarse Screen Shaker - 440 microns and larger.

b. Desanders -100 microns and larger.

c. Fine Screen Shaker - 44 to 74 microns and larger.

d. Mud cleaner -44 to 74 microns and larger.

e. Desilters - 15 microns and larger. 


\section{f. Centrifuge -4 to 8 microns and smaller.}

A typical drilling mud recycling system is shown in Figure 5.

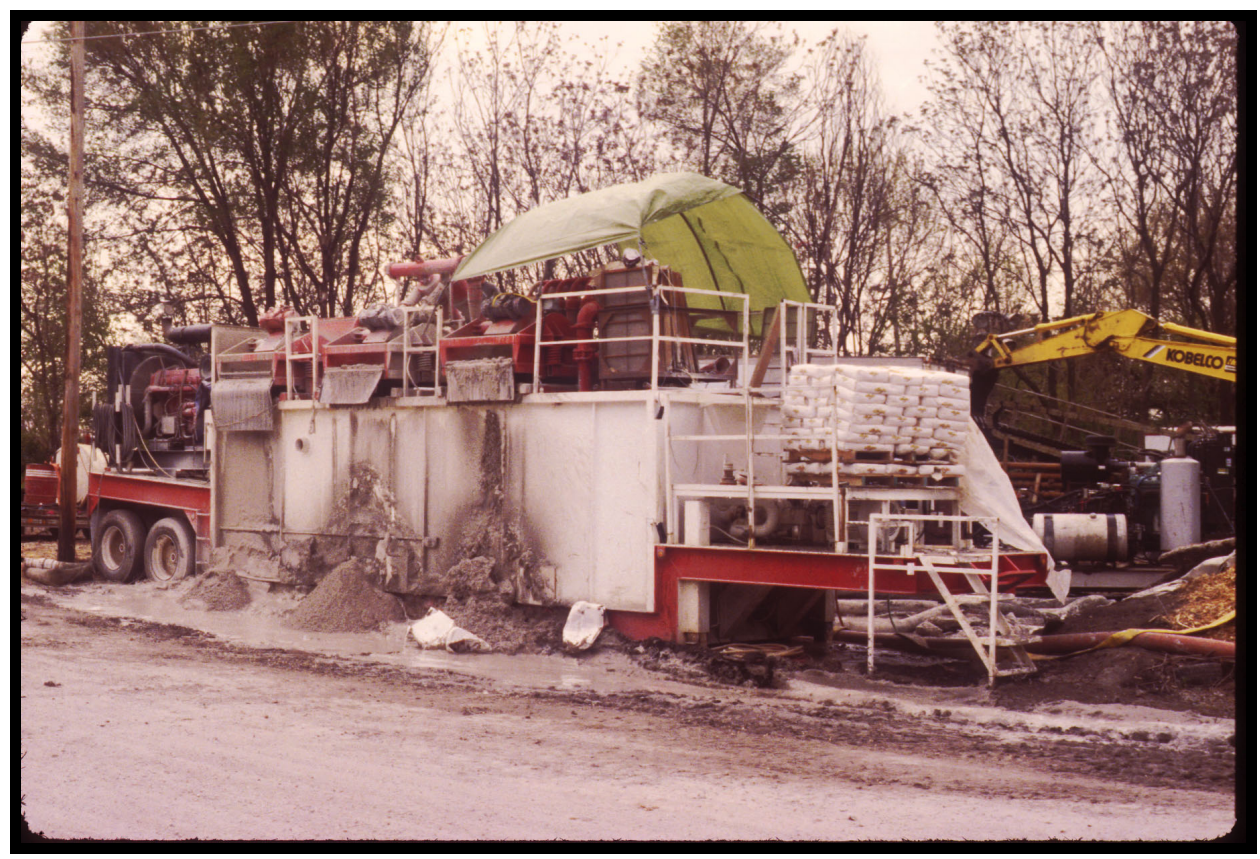

Figure 5. Drilling mud recycling system

The consistency of the spoil discharged from a solids control system may be similar to ready mix cement or a very viscous drilling fluid depending on factors such as the subsurface material being penetrated, drilling fluid properties, or the skill of the operator. An example of drilled spoil from rock drilling is shown on Figure 6.

\section{Hydrofracture or Inadvertent Returns}

HDD involves the use of high-pressure drilling mud that is discharged into the ground at the drilling bit or jetting tool. After being discharged, the drilling mud is relatively uncontrolled and will flow along the path of least resistance. If the annular space between the drill string and the borehole wall is kept clear and unobstructed, the drilling mud will follow the annular space back to the ground surface at the entrance or exit pit. If the annular space becomes blocked, the pressure of the drilling mud in the annular space will build up and may exceed the limiting strength of the borehole wall. At this point, a hydrofracture (inadvertent return) will occur and the drilling mud will be dispersed into the surrounding soils or discharged to the surface through a randomly created crack.

This is not a critical problem in an undeveloped location. The driller must only clean up the loose drill fluid that has reached the surface and this is 
accomplished by hiring an industrial vacuum truck operator to colect and properly dispose of the loose mud.

However, in the vicinity of a levee, a hydrofracture can be a much more serious problem. In addition to the obvious mess, the hydrofracture will crack the landside blanket and during the next flood will cause an increase in the seepage flows and seepage gradients in the vicinity of the crack. Drilling procedures must be adjusted to maintain drilling mud circulation and minimize the risk of hydrofractures. Maximum allowable pressures of the drilling fluid in the annular space must be estimated and these must be measured and controlled during drilling so that risks of hydrofracture are reduced. Nonetheless, the possibility of lost circulation and inadvertent returns cannot be

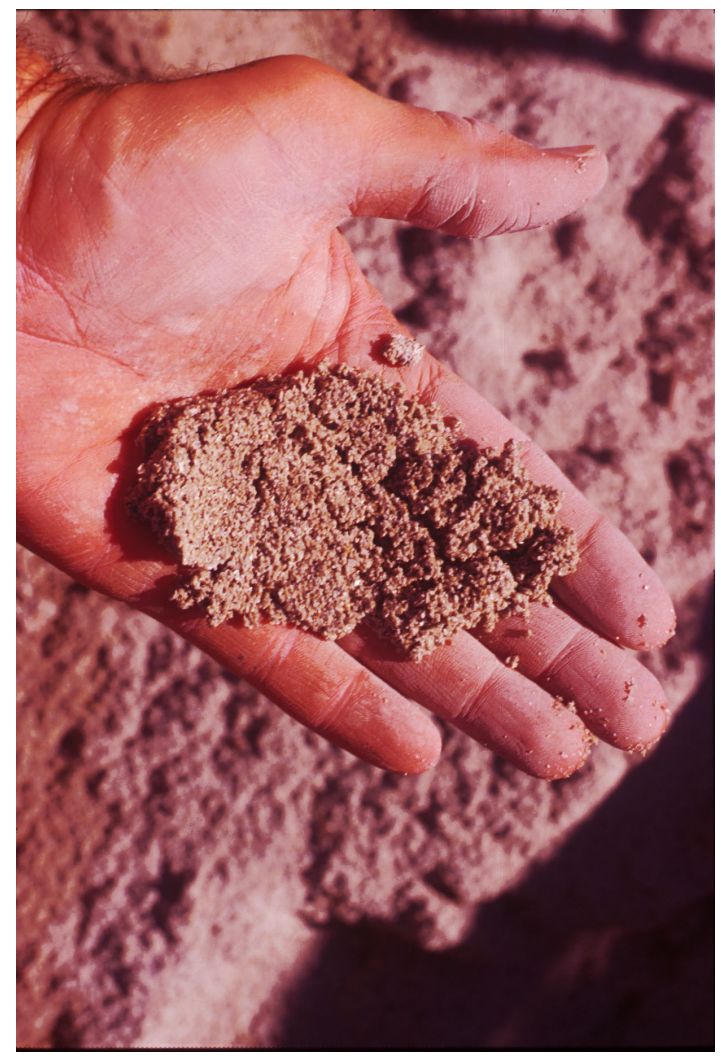

Figure 6. Typical spoil from rock drilling eliminated. Contingency plans addressing possible remedial action in case of a hydrofracture or circulation loss should be made during design.

\section{Downhole Surveying}

The actual path of the pilot hole is monitored during drilling by taking periodic readings of the inclination, orientation, and azimuth of the downhole probe. Readings are typically taken after drilling a single joint, or approximately every $9 \mathrm{~m}(30 \mathrm{ft})$. The measurement frequency can be increased, if necessary. These data are provided by the electronic survey probe installed in the drill string behind the drill bit. Transmission of this information to the surface is generally accomplished through a wire running inside the drill string. These readings, in conjunction with measurements of the distance drilled since the last survey, are used to calculate the horizontal and vertical coordinates of the downhole probe as it progresses along the pilot hole. Data and calculations from the readings typically include the following items:

a. Joint number. The joint number at which readings are taken by the downhole probe; joint numbers are usually tracked in a numerical sequence $(1,2,3 \ldots)$. 
b. Course length. The distance between two downhole surveys as measured along the drilled path. The summation of the course lengths becomes the measured distance.

c. Measured distance. The total distance of a downhole survey as measured along the drilled path from the entry point to the drilling tool.

d. Inclination. The angle at which the downhole probe is projecting from the vertical axis at a particular joint number; vertically downward corresponds to zero degrees.

e. Azimuth. The angle at which the downhole probe is projecting in the horizontal plane at a particular joint number; magnetic north corresponds to zero degrees.

$f$. Orientation. The rotational orientation of the drilling tool. Zero corresponds to the 12-o'clock position.

g. Station. The horizontal position of a downhole survey measured from an established horizontal control system.

h. Elevation. The vertical position of a downhole survey measured from an established vertical control system.

$i$. Offset. The distance of a downhole survey from the design path reference line; positive values indicate right of the reference line while negative values indicate left of the reference line.

Azimuth readings can be taken from the earth's magnetic field, but these are subject to interference from magnetic fields created by the downhole tools, drill pipe, and adjacent structures. Therefore, the probe must be inserted in a nonmagnetic collar and positioned in the string so that it is adequately isolated from downhole tools and drill pipe. The location of the downhole probe and the shape of the pilot hole path may also be tracked using a surface monitoring system, such as the TruTracker® System. These use a surface coil of known location to induce an artificial magnetic field at the ground surface. The downhole probe senses its azimuth relative to this induced magnetic field and communicates this information to the surface. This system is shown schematically in Figure 7. The inclination, orientation and azimuth of the drilling bit, and the measurements of the distance drilled since the last survey are used to calculate the horizontal and vertical coordinates along the pilot hole relative to the initial entry point on the surface.

\section{Pilot Hole Reaming}

Enlarging the completed pilot hole is accomplished using one or more reaming passes prior to pipe installation or simultaneously during pipe installation. To prepare for a reaming pass, the drilling tool is removed and replaced with a 


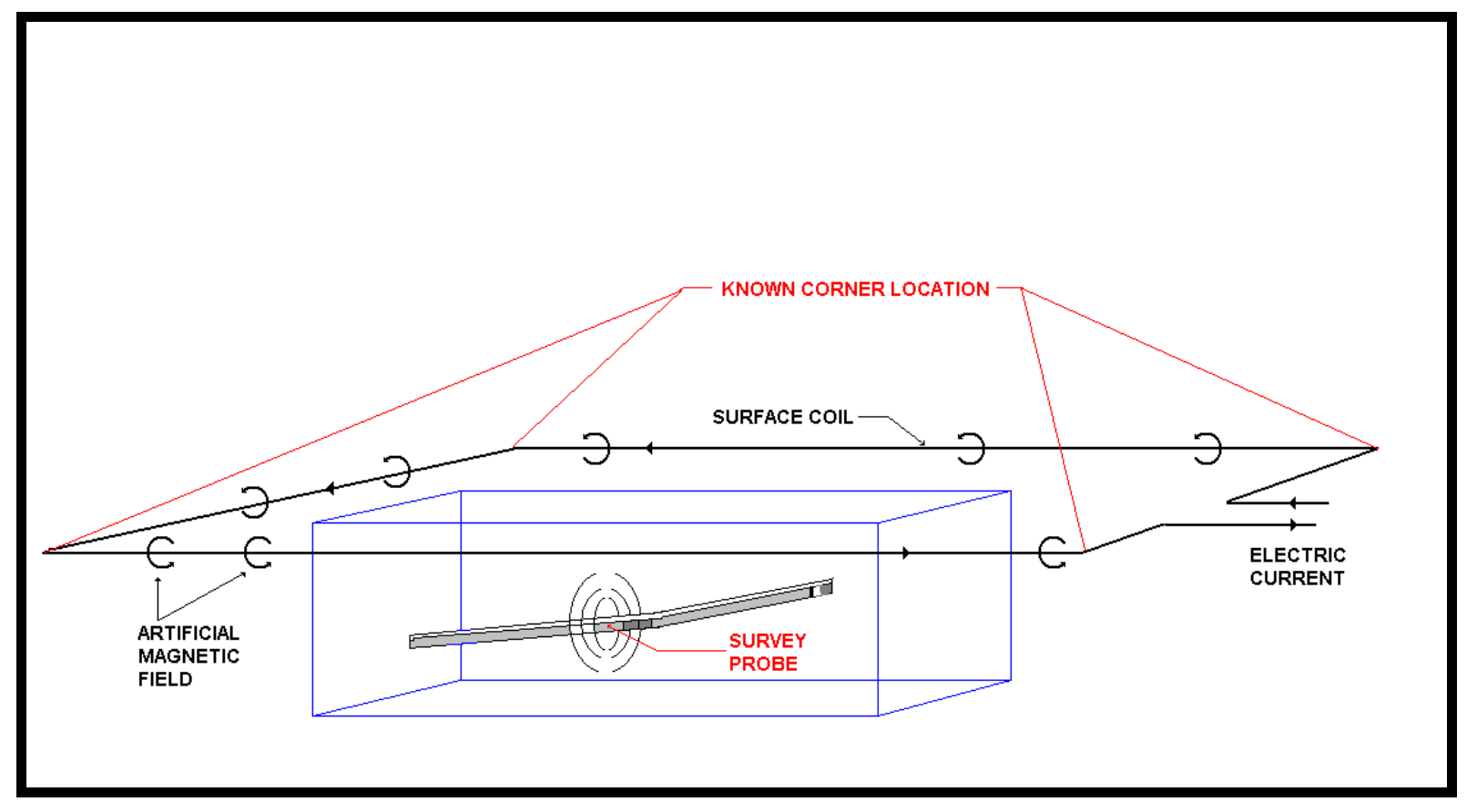

Figure 7. Schematic of surface monitoring

reaming bit. The reaming bit is drawn to the drilling rig, thus enlarging the pilot hole. Drill pipe is added behind the reamers as they progress toward the drill rig, ensuring that a drill string is always maintained in the drilled hole. During the reaming pass, drilling mud may be pumped to the reaming bit. Reaming tools typically consist of a circular array of cutters and drilling fluid jets and are often custom made by contractors for a particular hole size or type of soil. Examples of different types of reaming tools are shown in Figure 8.

\section{Pipe Pullback}

Pipe installation is accomplished by attaching the prefabricated pipeline pull section behind a reaming assembly at the exit point and pulling the reaming assembly and pull section back to the drilling rig. This is undertaken after completion of prereaming or, for smaller-diameter lines in soft soils, directly after completion of the pilot hole. A swivel is inserted between the pull pipe and the leading reaming assembly to minimize torsion transmitted to the pipe. The pull section is supported by a combination of roller stands, pipe handling equipment, or a flotation ditch to minimize tension and prevent damage to the pipe. Figure 9 shows examples of pipe pullback. 


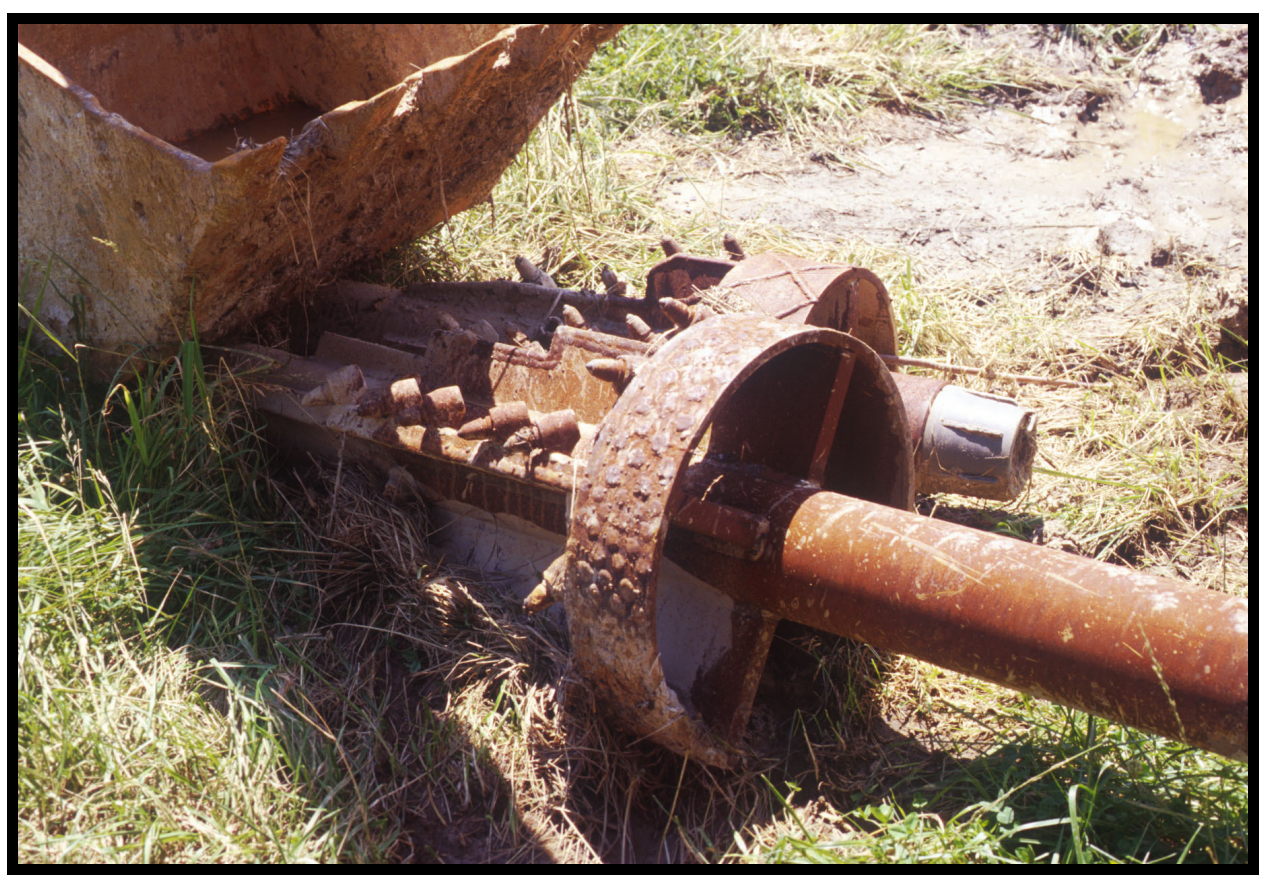

a. Soil reamer

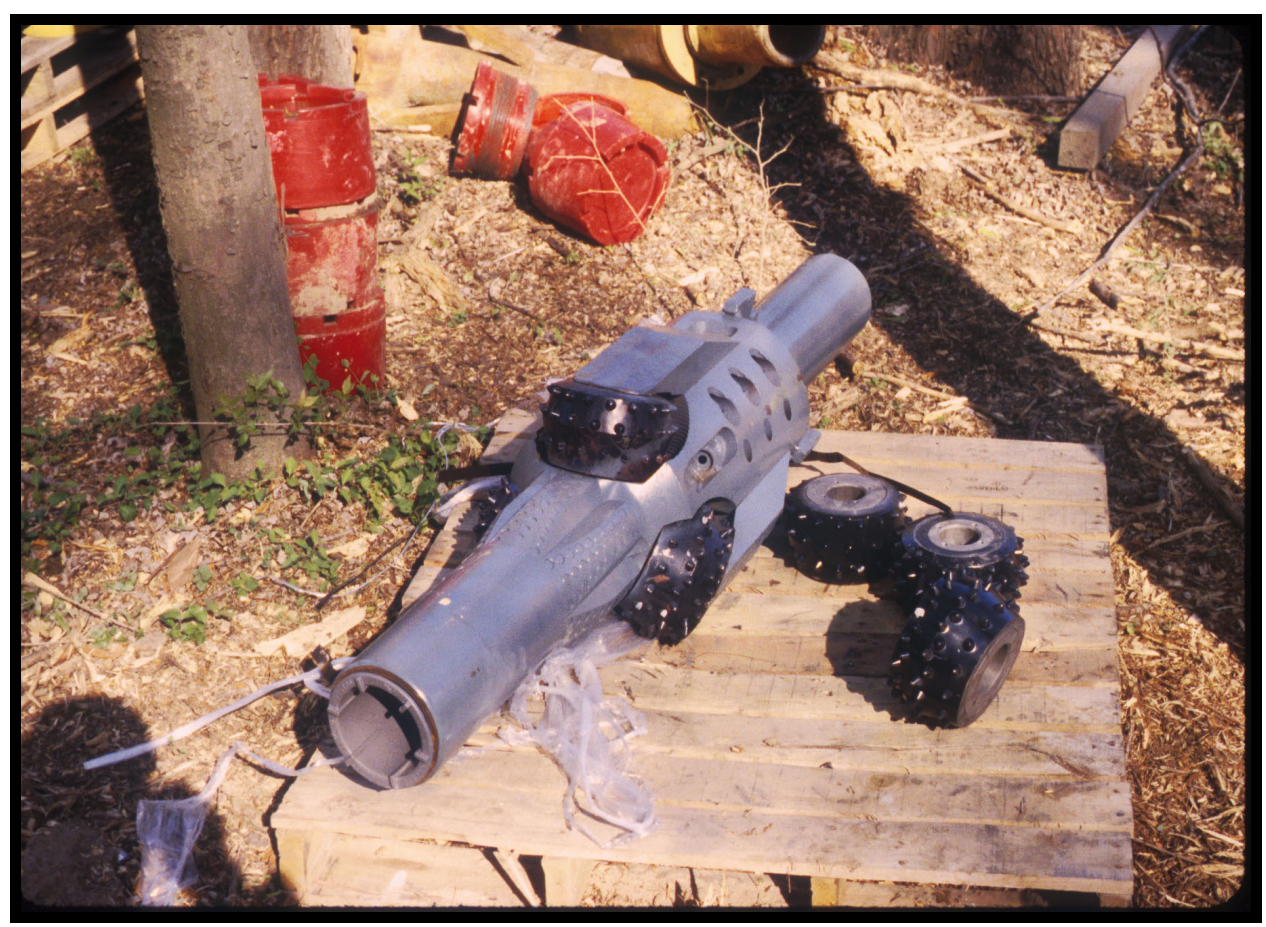

b. Rock reamer

Figure 8. Typical reaming tools 


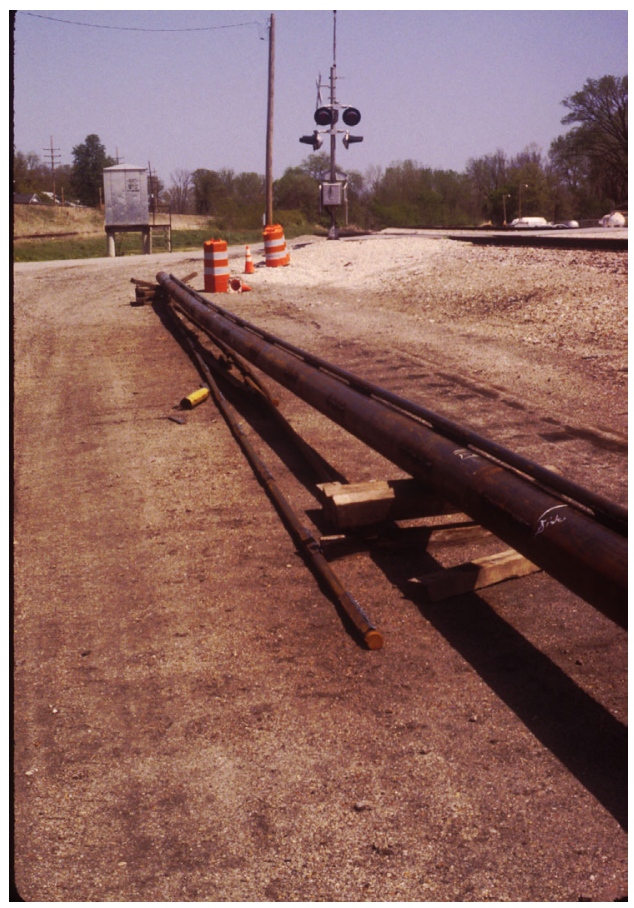

a. Casing layout prior to pullback

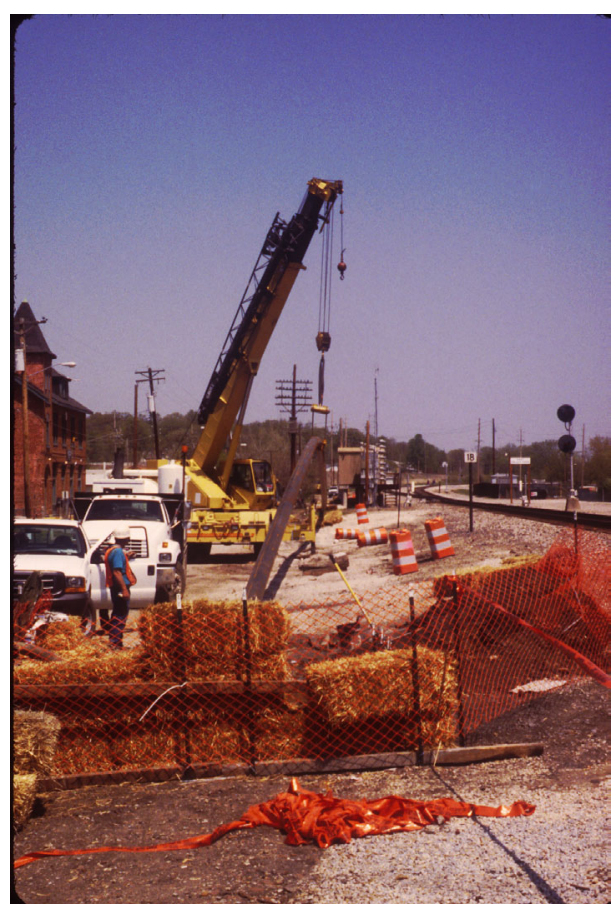

b. Casing breakover during pullback

Figure 9. Pipe pullback

\section{Maximum Allowable Annular Pressure}

In an HDD installation using a return mud flow, after the drilling mud exits the orifices in the drilling bit or the jetting tool, it flows back to the ground surface at the entrance pit through the annular space between the drill pipe and the borehole wall. If this annular space becomes blocked, the return flow is blocked and the pressure of the drilling mud will significantly increase. This pressure can build up to a level that exceeds the available strength of the borehole wall. At this point a hydrofracture occurs.

Staheli et al. (1998) provide an equation developed by Delft Geotechnic to estimate the maximum allowable pressure that can be developed in the annular space. The Delft equation is shown in Equation 1 and description of the nomenclature follows:

$p_{\text {max }}=u+p_{\text {max }}^{\prime}=u+\left(p_{f}^{\prime}+c \cdot \cot \phi\right) \cdot\left\{\left(\frac{R_{0}}{R_{p, \max }}\right)^{2}+Q\right\}^{\frac{-\sin \phi}{1+\sin \phi}} \cdot-c \cdot \cot \phi$

where

$p_{\max }^{\prime}=$ maximum allowable effective mud pressure in $\mathrm{N} / \mathrm{mm}^{2}$ 
$p_{f}^{\prime}=$ mud pressure at which the first plastic deformation takes place in

$$
\mathrm{N} / \mathrm{mm}^{2}, p_{f}^{\prime}=\sigma_{0}^{\prime} \cdot(1+\sin \phi)+\mathrm{c} \cdot \cos \phi
$$

$\sigma_{0}^{\prime}=$ initial effective stress in $\mathrm{N} / \mathrm{mm}^{2}$

$\phi=$ angle of internal friction in degrees

$c=$ cohesion in $\mathrm{N} / \mathrm{mm}^{2}$ (in undrained situation $c=c_{u}$ and $\phi=0$ )

$R_{0}=$ initial radius of the bore hole in millimeters

$Q=\sigma^{\prime}{ }_{0} \cdot \sin \phi+\mathrm{c} \cdot \cos \phi / \mathrm{G}$

$G=$ shear modulus in $\mathrm{N} / \mathrm{mm}^{2}$

$R_{p . \max }=$ radius of the plastic zone

$u=$ initial pore pressure in $\mathrm{N} / \mathrm{mm}^{2}$

To prevent blowouts, the plastic zone has to remain within a safe radius around the borehole. In clayey and peat layers, the maximum allowable radius of the plastic zone is chosen as $\left(R_{p, \max }\right)=\mathrm{H} / 2$ and in sand layers $R_{p, \max }=2 / 3 \mathrm{H}$, where $\mathrm{H}=$ height of the soil cover.

The appropriate geotechnical parameters needed to solve this equation can only be provided by a geotechnical exploration and soils testing program completed by geotechnical engineers experienced in this type of exploration and testing.

The typical working pressure of the drilling mud at the drill rig is on the order of 2 to $4 \mathrm{MPa}$ (300 to $600 \mathrm{psi}$ ). These pressures are reduced by frictional losses along the interior of the drill string, losses in the mud motor, expansion losses as the mud exits through the drill bit or jetting tool orifices, and losses resulting from turbulence at the drilling face. If the annular space becomes blocked, the drilling mud in the annular space will achieve similar pressures as exist just inside the drilling tool. Although frictional losses reduce the working pressure of the drilling mud as it travels from the drill rig to the drilling tool, the remaining pressures are adequate to cause a hydrofracture. It is important to use prudent drilling practices that maximize the return and reduce the chance of a blockage.

Prudent drilling practices include maintaining the forward progress of the drilling tool at a rate that is commensurate with the capability of the mud return flow to carry away the cuttings. In the industry parlance, 'Don't let the bit outrun the cuttings,' is applicable here. The mud return can be directly observed at the exit pit and correlated with the measured annular space pressure. If the mud return flow reduces or stops completely and there is a corresponding increase in the annular space pressure, it is likely that the cuttings are blocking the annular space. At this time, the forward progress of the drilling tool should 
be stopped and the drill bit moved back and forth in the borehole to wash away the blockage.

If the return flow stops but there is no corresponding increase in the annular space pressure, the drilling tool may have encountered a highly permeable zone (in soil) or a system of joints (in rock) that are the cause of the drilling mud loss. In this case, the driller may pump an extra thick batch of drilling mud downhole to plug up the formation responsible for the mud loss.

\section{Blockage of Preferred Seepage Paths}

The borehole diameter is typically 1.25 to 1.50 times the installed pipeline diameter. The District was concerned about this annular space acting as a conduit for seepage water during a flood. Even though the annular space would be filled with drilling mud at the end of the pipe pullback, the district took measures to ensure that this preferred seepage path would be blocked.

The boreholes would be drilled through the overlying clay blanket, coarsegrained aquifer, and the underlying bedrock. The existence of a mud-filled annular space in the sands and rock did not concern the district because:

a. Seepage flows occur naturally through the sands because of their porous nature. Even if the annular space were air filled, the overall increase in aquifer permeability in this localized area could not affect the overall seepage regime. More than likely, the annular space would be filled with a mixture of drill mud and sand, actually reducing the permeability.

$b$. Flow through the annular space through that part of the bore that is in rock is not considered. The rock lies below a significant thickness of coarse-grained sands and these sands would act as an infinite sink, absorbing any localized seepage flows where the borehole emerged into/out of the top of rock.

The occurrence of a mud-filled annular space in the overlying blanket was a significant concern. The artesian pressures acting at the bottom of the landside blanket during a flood are significant and there is a very real possibility that these pressures would wash out the drilling mud creating a very efficient flow path from the aquifer to the surface. The District ensured that the annular space in the landside blanket were grouted shut during construction.

The District also took measures to prevent seepage flows in the inside of the installed pipe from being able to exit into the protected area landside of a levee. The District assumed that a hairline crack would occur somewhere along casing length during its lifetime. Groundwater could enter the interior of the casing through this crack and flow through the casing to the landside. The District took steps to ensure that the end of the casing was embedded in a concrete block to seal off the end of the casing. The fiber cables were pulled through and splayed out in front of the casing so that the concrete could flow in and around the cables, effectively sealing the end of the casing. 


\section{Details of Field Work}

\section{General}

Table 1 presents general information on six HDD jobs that have been completed under levees within the boundaries of the District. This section will provide more detailed information on the studies that were completed for two of these projects.

\section{Mississippi River Crossing}

This project consists of a 25.4-cm (10-in.) steel casing bored under the Mississippi River at river mile 182.7 from the Metro East Sanitary District (MESD) on the Illinois side to the St. Louis City Flood Protection District on the Missouri side. Figure 10 shows the bore location on a regional view.

The bore diameter is $40 \mathrm{~cm}$ (16 in.) and the bore is $1,313 \mathrm{~km}(4,310 \mathrm{ft})$ long. The steel casing houses fiber-optic cables. The bore alignment was controlled with a downhole electronics survey probe sensing an artificial magnetic field created by an electric coil placed at the surface. Two coils were deployed; the first on the Illinois side and the second on the Missouri side of the river. While drilling under the river, the azimuth was controlled using the earth's magnetic field. While controlling the azimuth by the earth's magnetic field, some errors built up in the alignment which were corrected when the bore came under the influence of the Missouri surface coil. The plan views of the bore are shown in Figures 11 and 12. The plan view of the bore under the Mississippi River is not shown.

The bore entered the ground at a 15-deg entrance angle $247 \mathrm{~km}(810 \mathrm{ft})$ landside of the MESD landside levee toe. The bore continued through the overlying clay blanket, the silty sand, sand, and into the limestone bedrock. The angle of the bore was gradually flattened and the bore continued through the bedrock under the MESD levee, the Mississippi River, and the St. Louis City levee. Boring angle was gained gradually and the bore passed out of the bedrock and into the alluvial soils on the Missouri side. The bore reached the exit pit approximately $102 \mathrm{~m}$ (335 ft) landside St. Louis City levee. Figures 13 and 14 show the bore profile under the Missouri and Illinois sides of the river. 


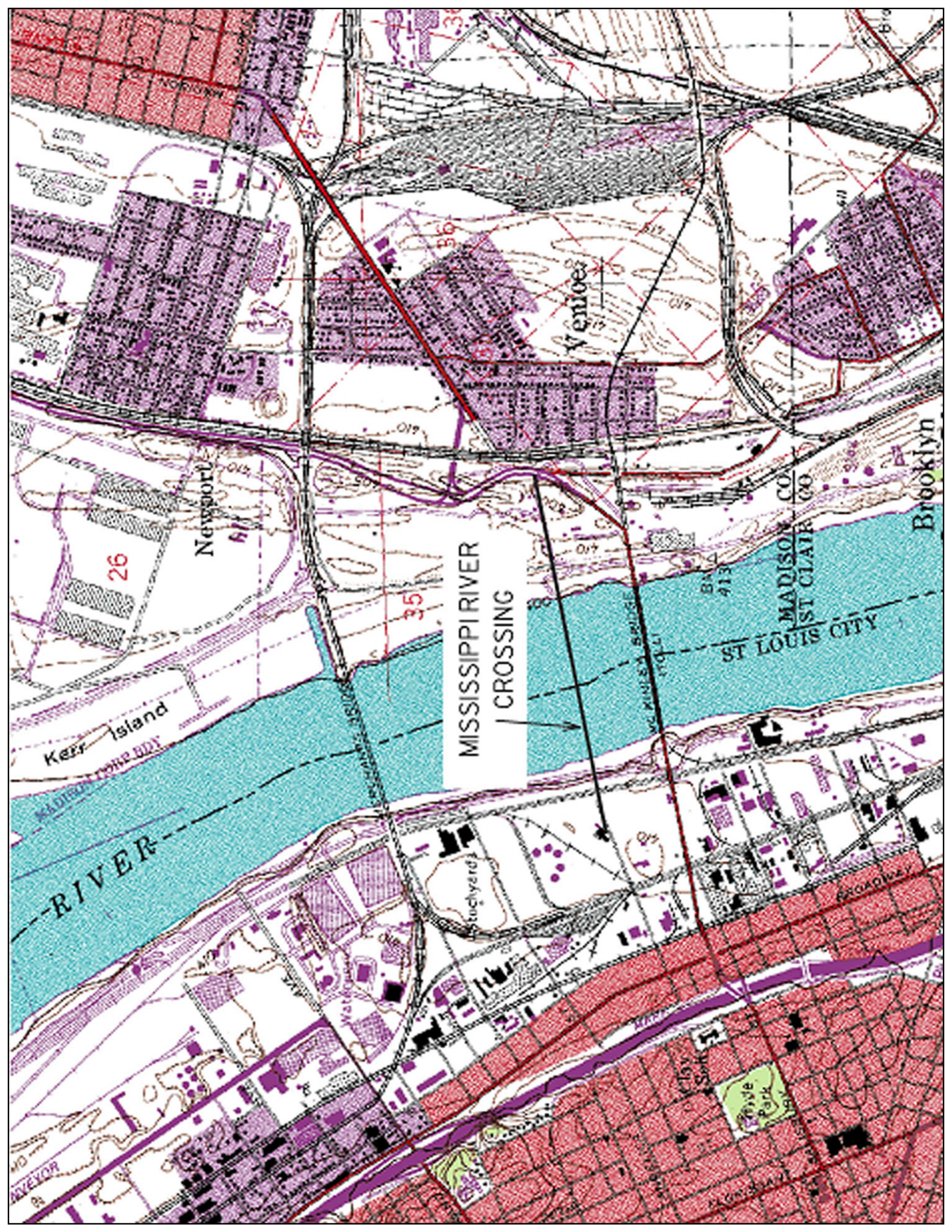

Figure 10. Regional view of Mississippi River bore 


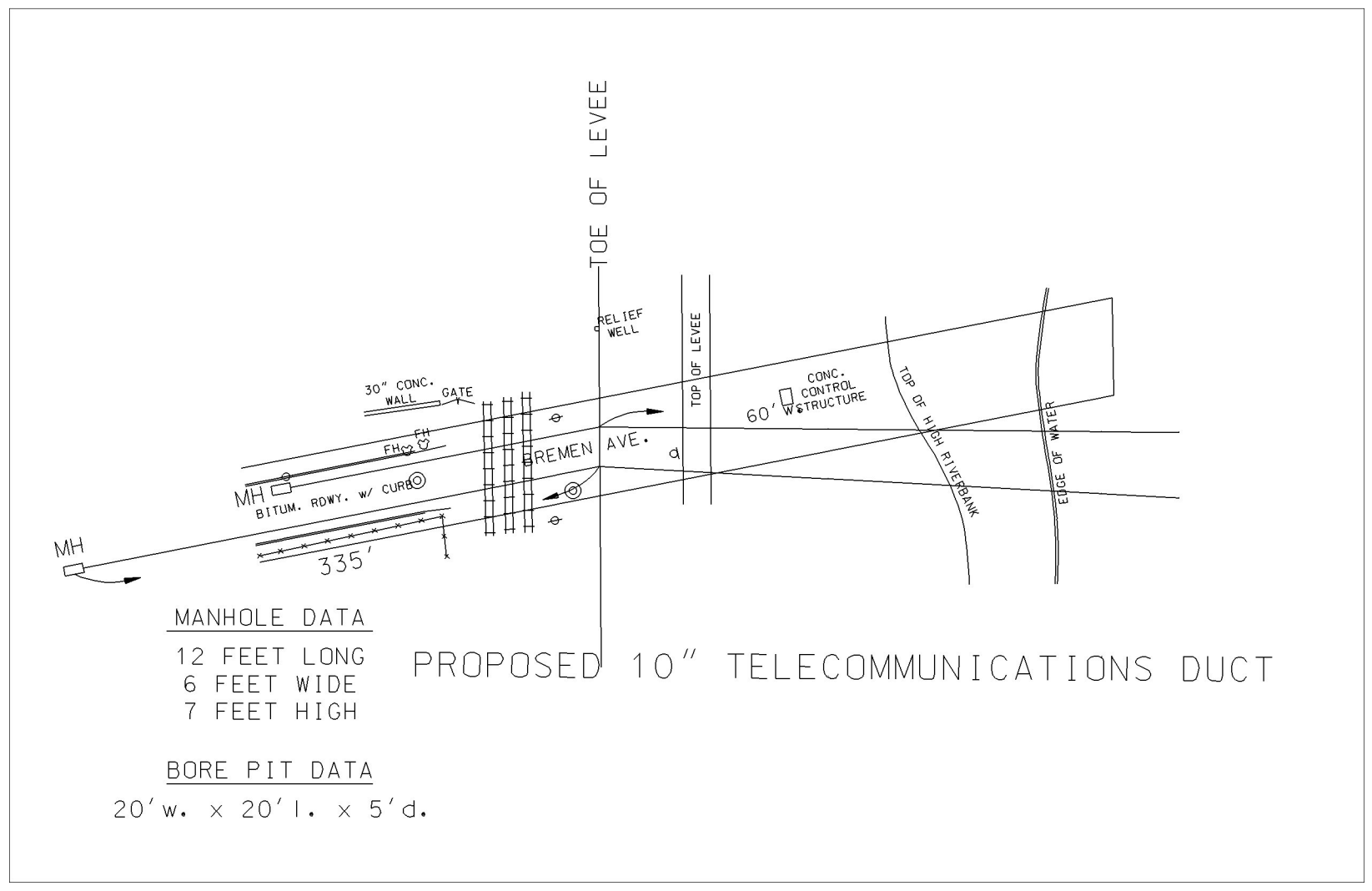

Figure 11. Missouri side plan view (To convert feet to meters, multiply by 0.3048 )

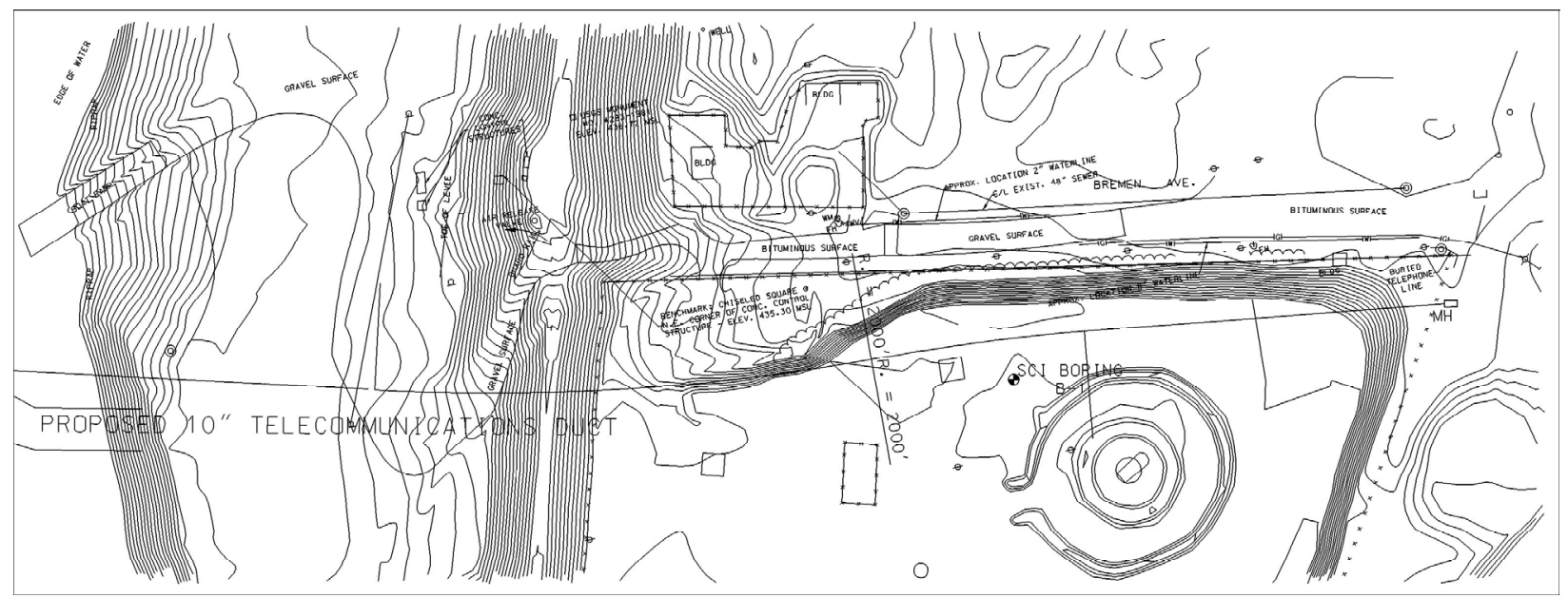

Figure 12. Ilinois side plan view 


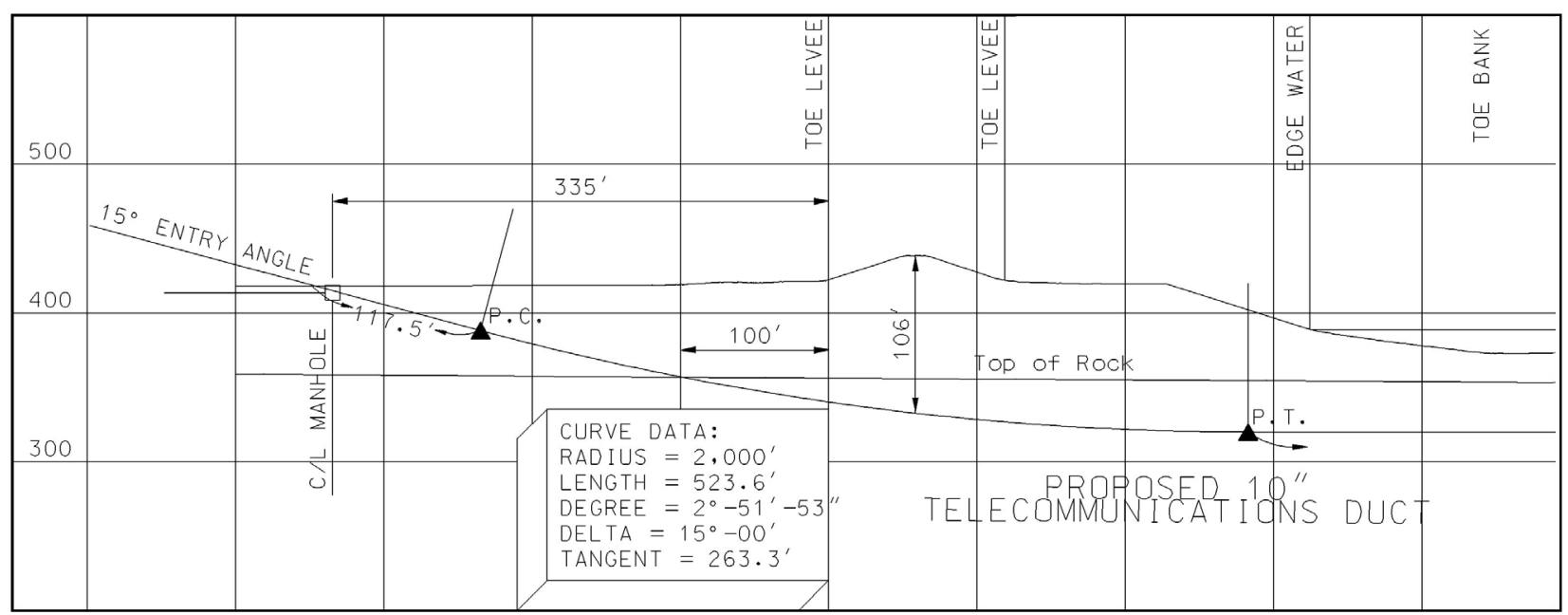

Figure 13. Bore profile under Missouri side (To convert inches to centimeters, multiply by 2.54 . To convert feet to meters, multiply by 0.3048 )

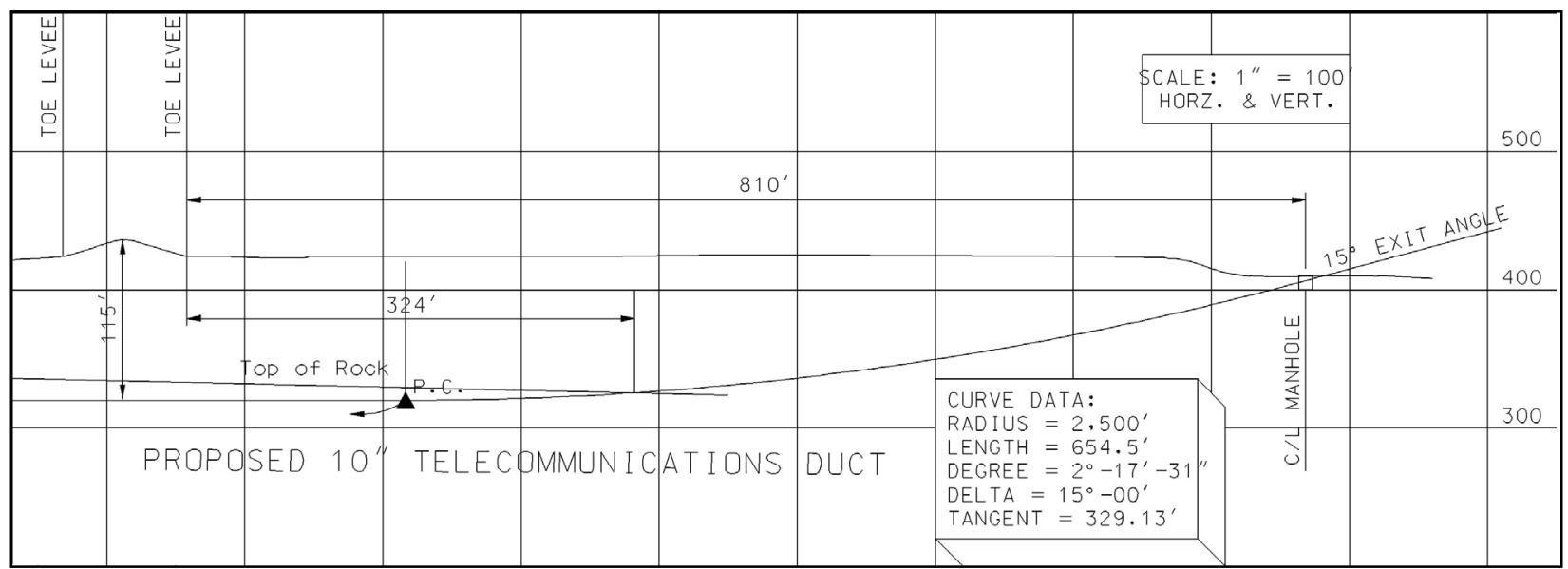

Figure 14. Bore profile under Illinois shore (To convert inches to centimeters, multiply by 2.54 . To convert feet to meters, multiply by 0.3048 )

The initial pilot hole diameter was $23 \mathrm{~cm}$ (9 in.). Two reaming passes were made to enlarge the hole to the final 41-cm (16-in.) diam. The 25-cm (10-in.) steel casing was welded together onsite and was pulled back during the second reaming pass.

The annular space was grouted shut using two different techniques. At the entrance pit, the HDD rig was used to insert $30.5 \mathrm{~m}$ (100 ft) of grout pipe between the steel casing and the borehole wall to the bottom of the fine-grained blanket. An expansive neat cement/pozzolan grout slurry was pumped through the grout pipe. During the grouting, the end of the steel casing was jacked up so that the grout could flow under the bottom of the steel casing. At the exit pit, the center line of the steel casing was located on the ground, and five vertical drill holes were drilled from the ground surface to the bottom of the steel casing with hollow-stem augers. PVC grout pipes were installed in the augers and left 
in-place as the augers were withdrawn. The grout was injected until all subsurface void space intersected by the grout holes was filled and sealed.

Twenty-two high-density polyethylene (HDPE) innerducts were pulled through the steel casing and fiber-optic cables were subsequently pulled through four of these. The 18 remaining HDPE innerducts are spares and represent additional capacity that can be used as the need arises.

Handholes were placed on each end of the bore to provide a junction box for fiber-optic cable splicing. The steel casing was cut off approximately $61 \mathrm{~cm}$ (24 in.) outside of the handhole and did not enter the handhole. The HDPE innerducts were splayed out and pulled into the handhole. The space between the end of the steel casing and the handhole was filled with concrete. The concrete was worked between the innerduct conduits.

The owner of this project is American Fiber Comm (2000), Edwardsville, IL, and the Consulting Engineer is Sheppard, Morgan, and Schwaab, Alton, IL. The exploration program was completed by Shannon and Wilson Geotechnical Engineers, St. Louis, MO, and SCI, Fairview Heights, IL. Tom Allen Construction, Edwardsville, IL, completed the directional drilling.

\section{Wood River Crossing}

This project consists of a 10-cm (4-in.) steel casing bored under the Cahokia Diversion Canal from the MESD to the Wood River Levee District. The bore is located immediately adjacent to Illinois Highway 3, approximately $1.6 \mathrm{~km}$ (1 mile) upstream of the confluence of the Cahokia Diversion Canal and the Mississippi River. The steel casing houses fiber-optic cables. The total length of the completed bore is $846 \mathrm{~m}(2,778 \mathrm{ft})$. Figure 15 locates the crossing on a regional view.

The 23-cm (9-in.)-diam pilot bore was controlled with a downhole electronics survey probe sensing an artificial magnetic field created by an electric coil placed at the surface. The coil was deployed from the MESD side, strung across the Cahokia Diversion Canal to the Wood River side. The bore enters the ground approximately $183 \mathrm{~m}(600 \mathrm{ft})$ from the landside toe of the MESD levee and exits $244 \mathrm{~m}(800 \mathrm{ft})$ landside of the Wood River levee landside toe. From the entrance pit, the bore goes through the unconsolidated overburden and into bedrock. The bore continues through the bedrock under the MESD levee, the canal, and the Wood River levee. The bore exits the bedrock and surfaces in the exit pit. Figures 16 and 17 show the plan and profile of the Cahokia Creek Crossing.

The initial pilot hole is $23 \mathrm{~cm}$ ( 9 in.) in diameter. One back pass was made subsequent to the pilot hole. During this pass, a packing reamer was pulled through immediately ahead of the steel casing. The annular space at the entrance and exit pits was grouted shut in similar manners as described for the Mississippi River crossing. 


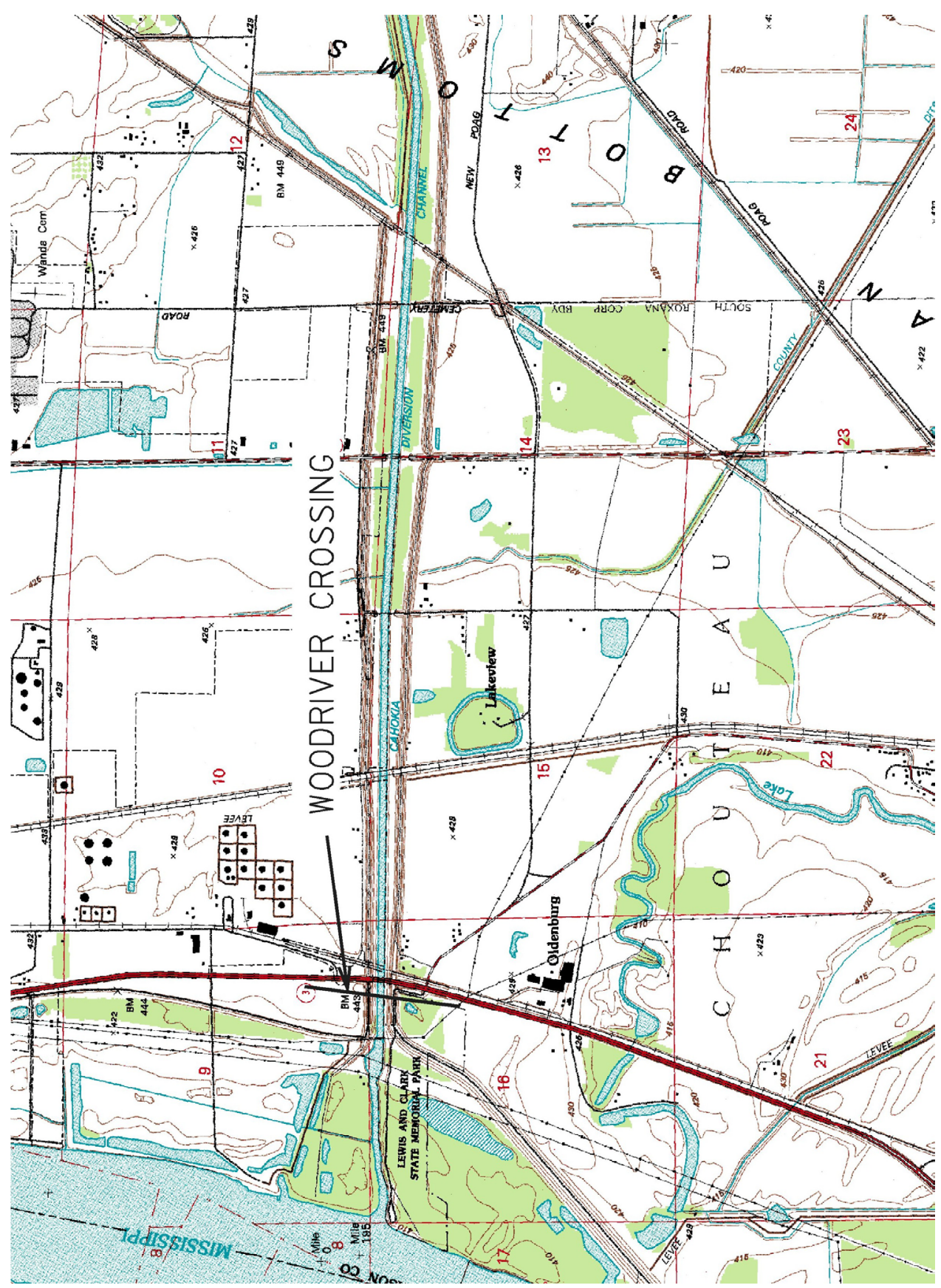

Figure 15. Regional view of Cahokia Creek Crossing 


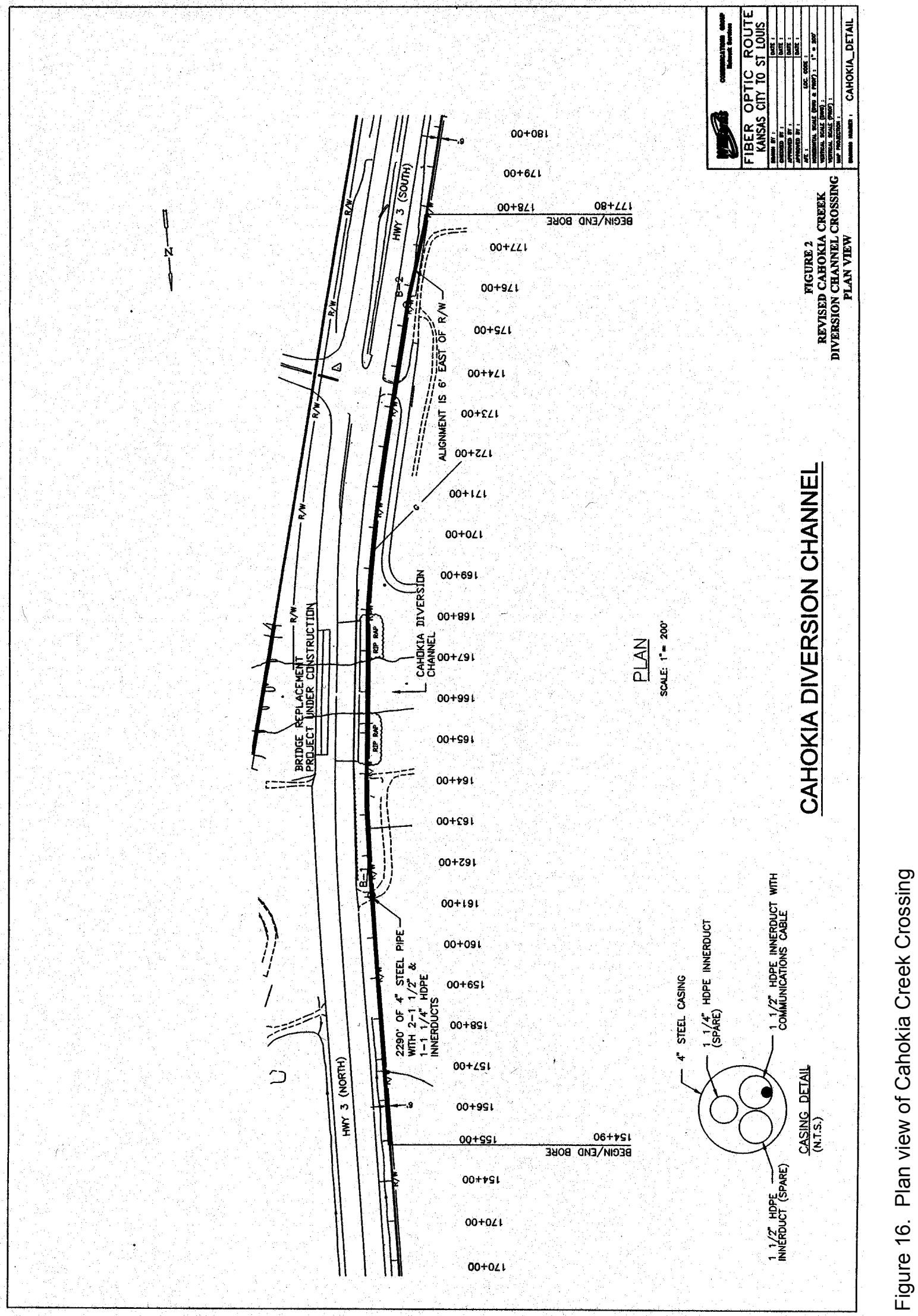




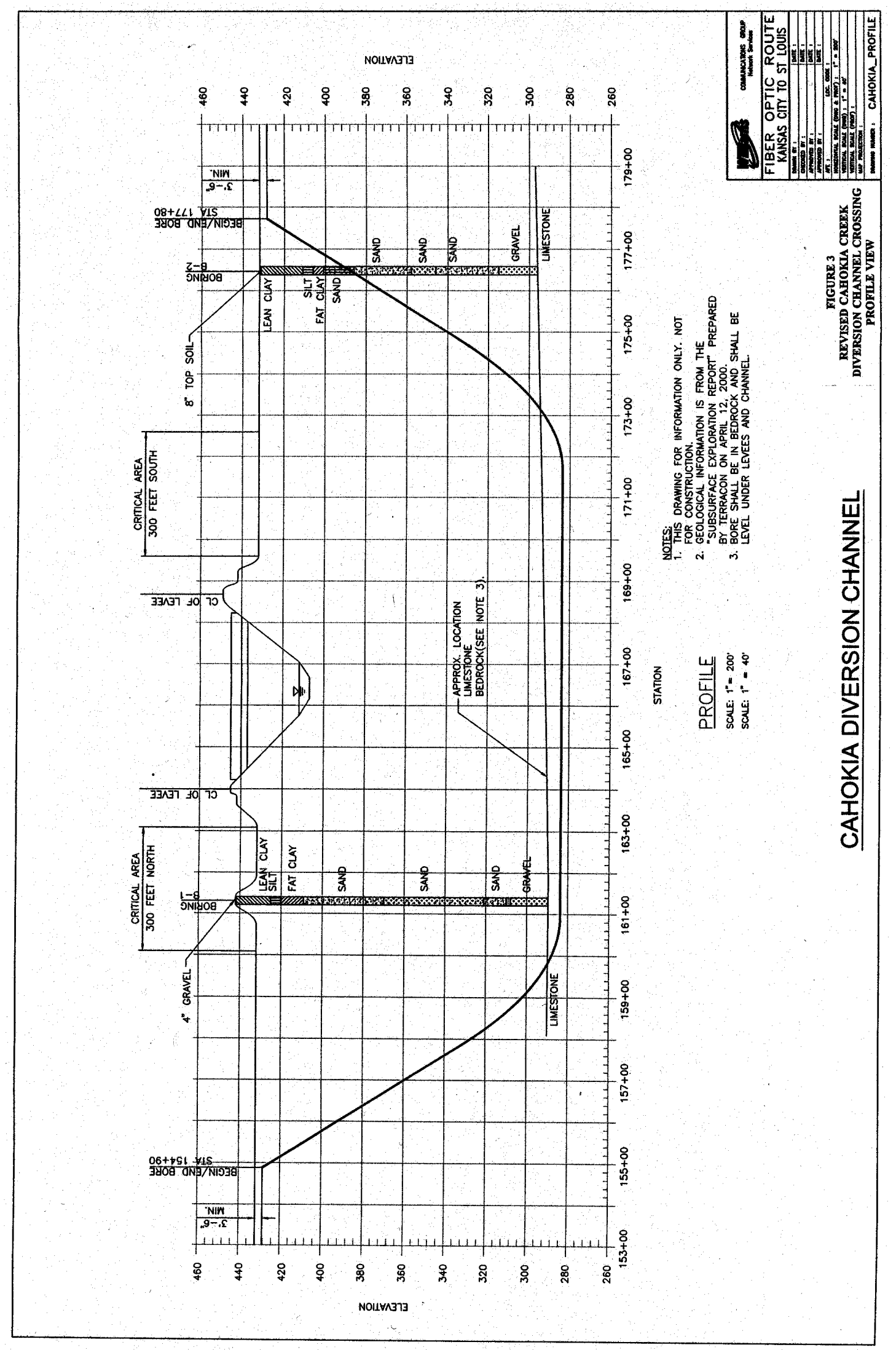

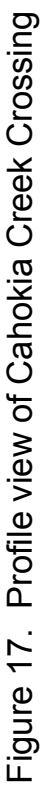


Three HDPE innerducts were pulled through the casing and one of these was populated with a fiber-optic cable. The two remaining innerducts are spares. Handholes were placed on each end of the bore to provide a junction box for splicing the fiber-optic cables. The steel casing was cut off approximately $61 \mathrm{~cm}$ (24 in.) outside of the handhole and did not enter the handhole. The HDPE innerducts were splayed out and pulled into the handhole. The space between the end of the steel casing and the handhole was filled with concrete. The concrete was worked in-between the innerduct conduits.

The owner of this project is the Williams Communication Company. The Consulting Engineer was Burns and McDonnell Engineers-ArchitectsConsultants, Kansas City, MO. Terracon, St. Louis, MO, completed the exploration program. Mears/HDD Directional Drilling Services, Rosebush, MI, completed the directional drilling.

\section{Geotechnical and Geological Investigation}

The HDD boreholes described herein were drilled under existing flood control levees in the City of St. Louis Flood Protection District, the MESD, and the Wood River Levee District. The District provided pertinent geotechnical and geological exploration data to the engineering firms designing the HDD bores. Although this information provided a generalized idea of the subsurface conditions, it did not provide the necessary site-specific information needed to complete the design. The engineering firms were required to obtain site-specific geotechnical exploration and testing.

Exploratory borings were completed near the entrance and exit pits of the HDD bores. Borings were advanced with truck mounted rotary drill rigs using continuous flight hollow stem augers above the groundwater and mud rotary methods below the groundwater table. Representative samples were obtained using thin-walled sampling tubes in the fine-grained soils and standard split spoon sampling procedures in the coarse-grained soils. Borings were advanced 8 to $16 \mathrm{~m}(25$ to $50 \mathrm{ft})$ into the bedrock obtaining NX-size rock cores.

Fine-grained soil samples were tested for natural moisture content, Atterberg Limits, unconfined compressive strength, and dry density. In some instances, the unconfined compressive strength was interpreted by hand-held penetrometers. The drained shear strength of the fine-grained soils was inferred by empirical methods based on the Atterberg limits of the soils. Sieve analyses were performed to determine the particle-size distribution of a few of the coarsegrained samples. The shear strength of the coarse-grained soils was inferred by empirical methods based on the Standard Penetration Rates (Blow Counts) and the soil's classification. The rock quality index (RQD) of all rock cores was determined.

All soil samples were classified according to the Unified Soil Classification System and all results of the exploration and tested plotted on boring logs. These boring logs for the Mississippi River Crossing are shown in Figure 18. The borings for the Cahokia Creek Crossing are shown on Figure 19. This exploration 

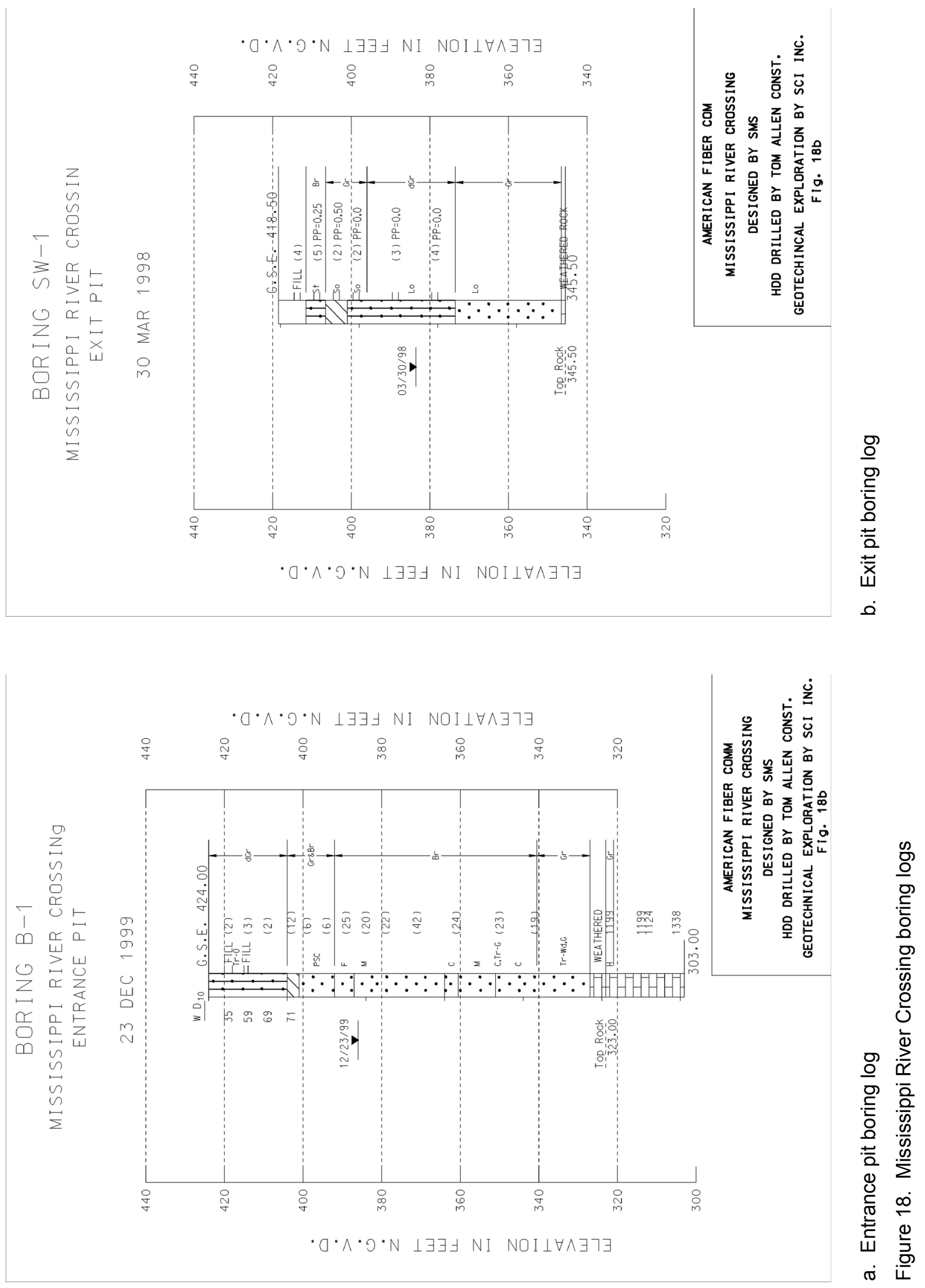


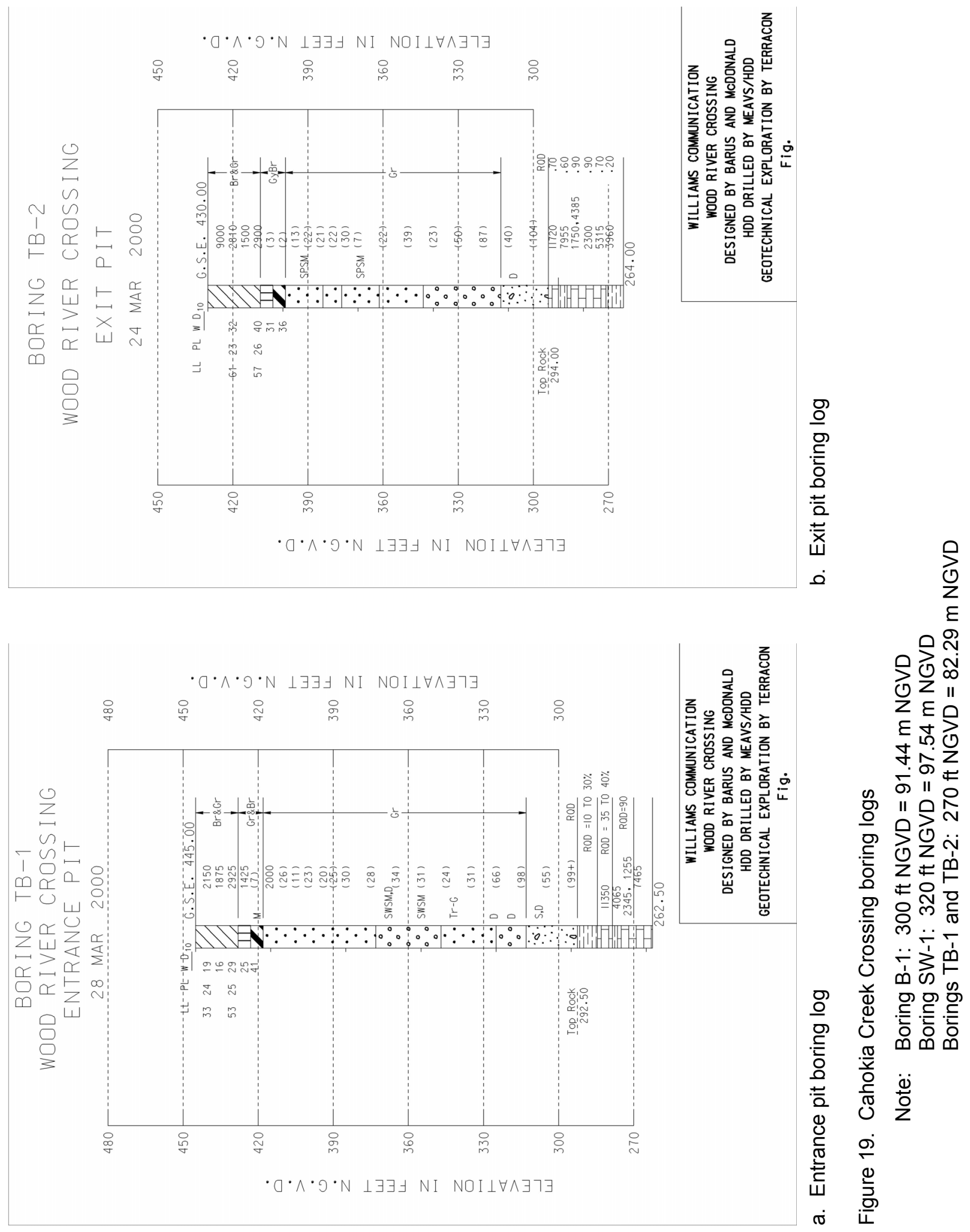


shows that the stratigraphy consists of a fine-grained blanket of clays and silts overlying a coarse-grained aquifer of medium to coarse sands.

\section{Topographical survey}

The ground surface along the proposed borehole centerline was surveyed to determine the horizontal and vertical extents of the surficial physical features. The results of any existent hydrographic surveys of the adjacent rivers were incorporated into the survey. In the vicinity of the entrance pit, an additional area sufficiently large as to hold the drilling equipment and support vehicles was surveyed. In some cases, the area for some distance beyond the exit pit was surveyed to verify its usefulness as a pipe string layout area during the pipe pullback. These surveys included the locations of all known surface and subsurface utilities, locations that were ultimately field-verified at the onset of construction.

\section{Plan and profile of drill path}

As stated earlier, the design plan and profile of the drill path depends on many factors including the entry and exit points, entry and exit angles, radius of curvature that can be tolerated by the permanent casing, points of curvature and tangency, depth of existing obstacles (in this case the Mississippi River and the Cahokia Diversion Canal) and required depth of cover over the completed casing. The Geotechnical Branch of the District added the following requirements to the drill path design:

a. Landside entrances or exit pits must be located at least $91 \mathrm{~m}(300 \mathrm{ft})$ landside of any landside levee toe. The $91-\mathrm{m}$ (300-ft) landside setback is taken from a traditional practice used by the District in seepage berm design. Although the closed-form solutions used in seepage berm design

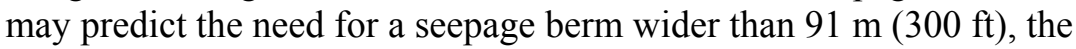
District never builds berms wider than $91 \mathrm{~m}(300 \mathrm{ft})$. Although substantial efforts have been made to prevent preferred seepage paths from occurring at the landside exit/entrance pits, the District is confident that the 91-m (300-ft) offset will preserve levee integrity, should leakage occur.

b. Riverside exit pits must be located at least $15.3 \mathrm{~m}(50 \mathrm{ft})$ riverside of any riverside levee toe. This requirement was put in place to provide a $15.3-\mathrm{m}(50-\mathrm{ft})$ buffer between the exit pit and the levee. This buffer would provide additional space so that any alignment errors in the drill path could be corrected and keep the bore from exiting in the net levee section.

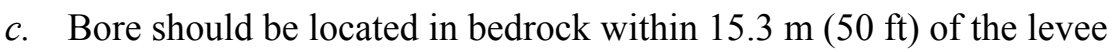
footprint. This requirement takes advantage of the favorable stratigraphy (top of rock is within a reasonable depth) within the District. Also, this 
requirement guarantees that if hydrofracture were to occur, the damage would be limited to areas outside of the net levee section.

\section{Allowable Pressures in Annular Space}

The Geotechnical Branch of the District was very concerned about the potential for hydrofracture and decided that the HDD drilling procedures should limit the residual drilling mud pressure in the annular space between the drill pipe and the borehole wall. The equation presented in "Installation of Pipelines Beneath Levees Using Horizontal Direction Drilling” (Staheli et al. 1998) was used to predict the maximum allowable pressure in the annular space. Appendix B of the referenced report was created by the Foundations and Underground Engineering Department of Delft Geotechnics for CPAR-GL-98-1 (Staheli et al. 1998). The predicted maximum allowable pressures were set as the limiting mud pressure during the drilling.

The various parameters required by the Delft Equation were provided by the soils exploration and testing program described and recommendations made in CPAR-GL-98-1 (Staheli et al. 1998). Tables 3 and 4 show the supporting calculations and the limiting mud pressures for the two sites.

Maintaining the return flow of drilling mud is critical to prevention of hydrofracture. The return flow is maintained as long as the annular space between the borehole wall and the drill stem remains open to the return flow. If careful drilling practices are not adhered to, the cuttings can block the annular space resulting in a dramatic increase of pressure. It is this blockage of the return flow and subsequent increase in drill fluid pressure above the allowable that will cause hydrofracture. The careful drill practices that tend to keep the annular space clear and maintain the return flow are:

a. Keep rate of advancement under control. The drilling contractor should keep the rate of advancement of the drill bit commensurate with the capability of the drilling mud system to flush out the cuttings. In other words, 'do not outrun the cuttings.'

$b$. Keep the borehole clean by swabbing it. Swabbing involves alternately retrieving and advancing the drill bit the length of one drill stem (about $9.1 \mathrm{~m}(30 \mathrm{ft})$ ) while pumping. This allows more of the cuttings to be flushed back to the surface.

c. Monitor all available instrumentation and continually adjust the drilling process. Rig thrust, annular pressure, drilling torque, drilling thrust, and differential pressure across the mud motor are all indicators of drill bit advancement or seizure. These parameters will change continuously throughout the bore as the bit encounters differing soil/rock conditions. An experienced driller knows the appropriate relationships between these measurements and will continually adjust the drilling process to the soil conditions. 


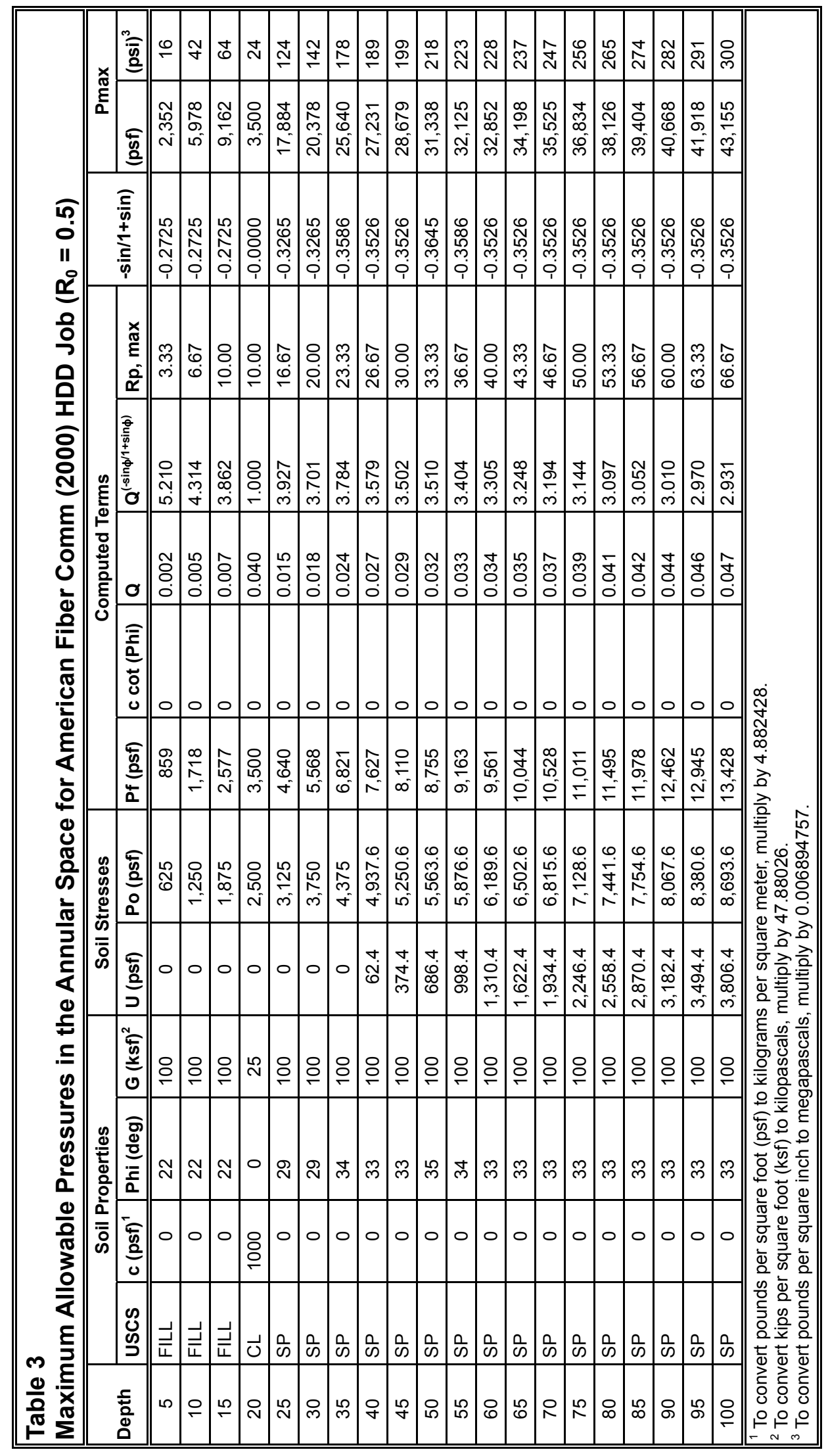




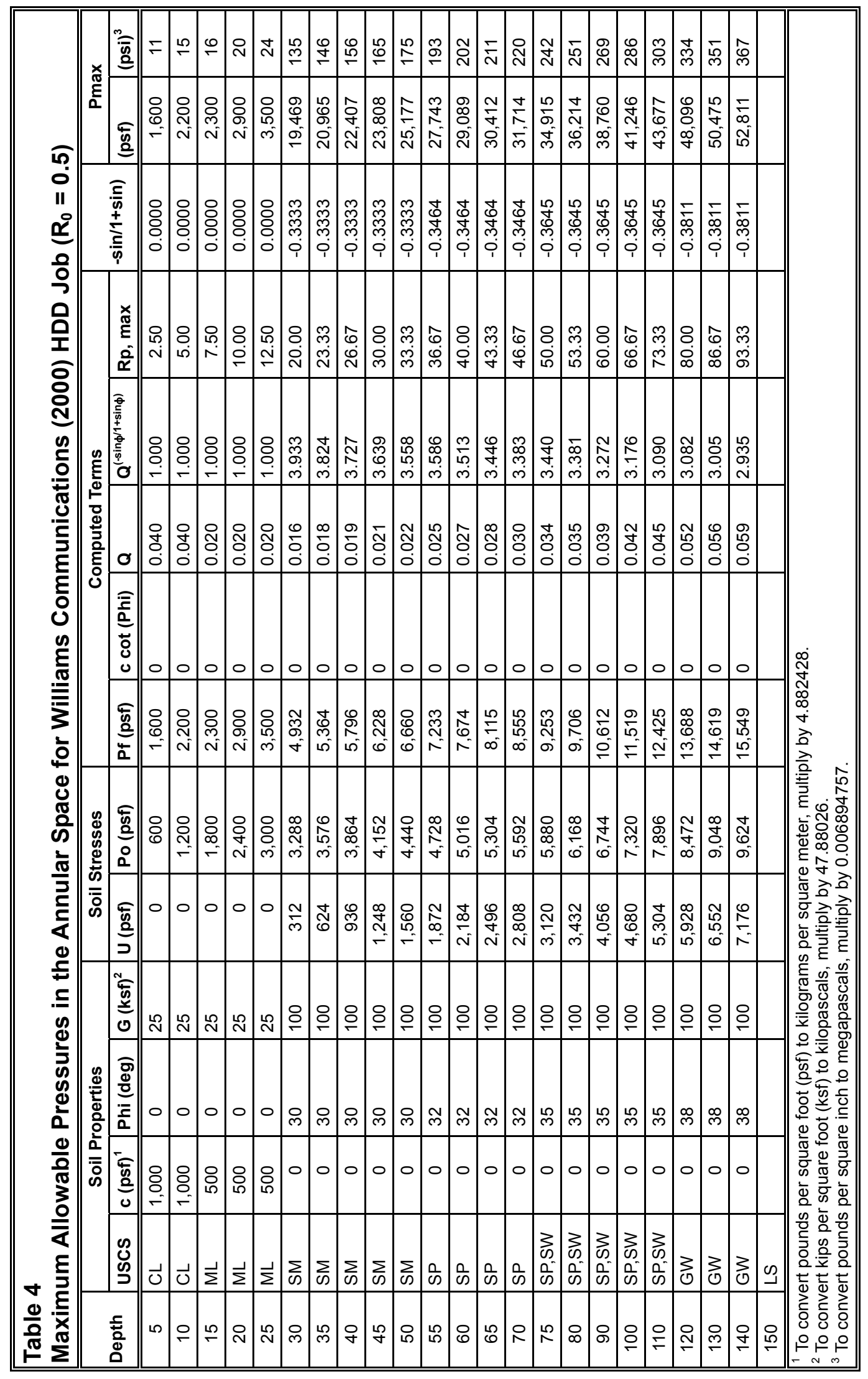




\section{Measurements of Drilling Mud Pressure in the Annular Space}

While drilling in the vicinity of these local flood protection levees, the Geotechnical Branch of the District required the contractor to measure the residual pressure of the drilling mud return flow in the annular space between the borehole wall and the drill string. The specifications required the contractor to measure these pressures at $30-\mathrm{cm}(1-\mathrm{ft})$ increments of depth while drilling in soils and 1.5- to 4.6-m (5- to 15-ft) increments while drilling in rock. The contractor's control system was capable of making many more measurements than required by the specifications. The contractor provided measurements on almost a minute-by-minute basis; collecting up to 4 doz pressure measurements per joint. Figures 20 and 21 show the measured annular pressures, allowable maximum annular pressures shown in Tables 3 and 4, and the static pressure of the drilling fluid based on a unit weight of $1,174 \mathrm{~kg} / \mathrm{m}^{3}$ (72 pcf).

The measured annular pressures are generally lower than the calculated allowable pressures except near the end of each bore. Near the end of both bores, and most notably the last four data points of the Mississippi River Crossing (Figure 21), the measured pressures exceed the maximum allowable pressure predicted by the Delft equation. This would indicate that a hydrofracture should have occurred, but no hydrofracture was observed.

In the Williams Communications bore (Figure 20), the measured pressures increase substantially between measured depths of 213 to $670 \mathrm{~m}$ (700 to 2,200 ft), while the bore path is within the rock. Within this reach, in the vicinity of $580 \mathrm{~m}(1,900 \mathrm{ft})$, there is a spike to over $1,551 \mathrm{KPa}(225 \mathrm{psi})$ in the measured pressure. A closer inspection of these data shows that the measured pressures generally remain low from where the bore enters the rock and for another $45 \mathrm{~m}$ $(150 \mathrm{ft})$. These data also show that the pressures drop significantly beginning

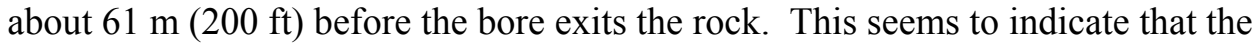
driller took advantage of knowing that the drill bit was in strong rock and that he could safely increase his production rates without risking hydrofracture. These data also indicate that the driller scaled back his production rates when he knew that the bore was about to exit the strong rock and reenter the soils. The $1,551 \mathrm{KPa}(225 \mathrm{psi})$ spike occurred while the bore was in rock and presented no risk of hydrofracture.

\section{Technical Specifications}

The District worked closely with the owner's consulting engineers to develop technical specifications that would control the drilling processes and protect the integrity of the flood protection project. The owner included these technical specifications in the contract documents. Appendix A is an example of technical specifications. 


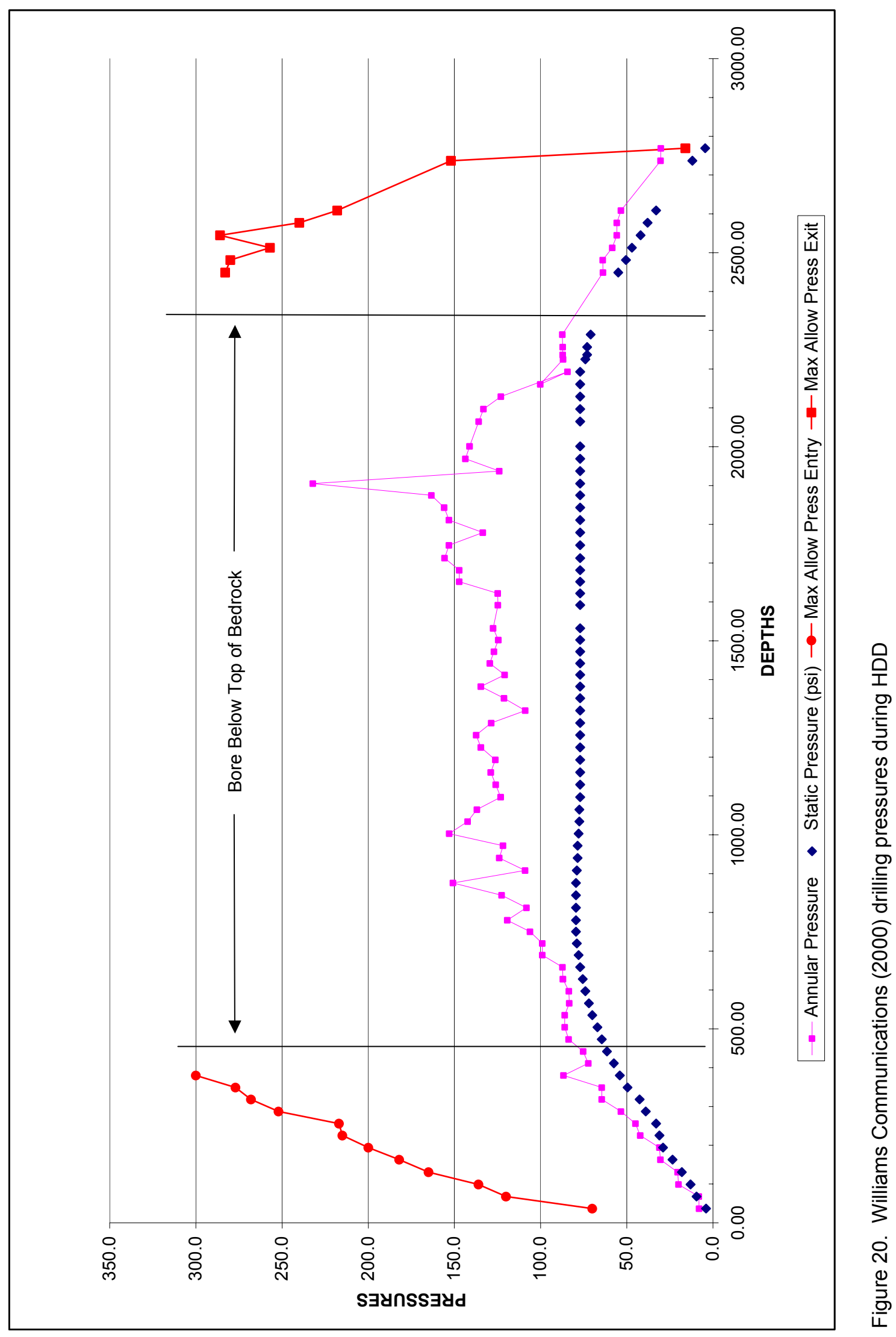




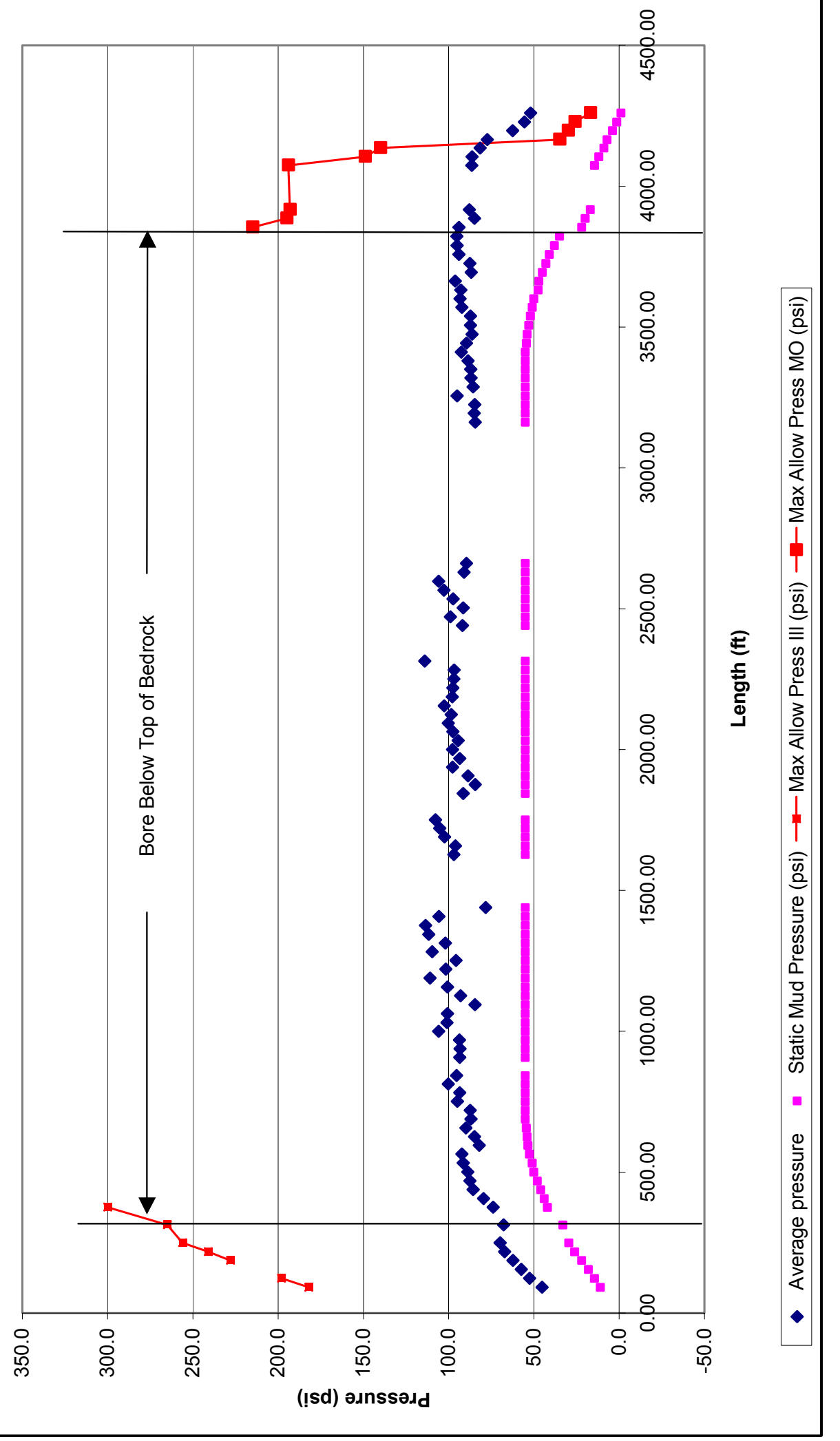

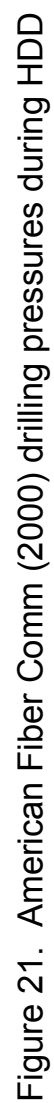




\section{Conclusions and Recommendations}

\section{Conclusions}

The technology, methods, and hardware exist to allow the owner and engineer to predict and measure drilling mud pressure in the annular space between the drill string and the borehole wall. These pressures must be controlled so that hydrofracture does not occur. The conditions that lead to pressure increases and subsequent hydrofracture can be monitored and controlled by adjusting the directional drilling process.

As in all construction projects, good contractual documents are needed to obtain the desired quality product. Such contract documents have been produced for using HDD techniques to install fiber-optic cables under flood protection levees.

As in any important construction project, good working relationships among the owner, engineer, and contractor must be developed to ensure a smooth running job. Corps of Engineers geotechnical engineers must be present to explain the Corps' needs to owners and HDD drilling contractors. Many owners and HDD drilling contractors are unaware of the unique geotechnical features associated with Corps of Engineers flood protection levees. It is imperative that Corps Geotechnical engineers become involved with the HDD job to explain the reasons behind the technical requirements built into the specifications. The geotechnical engineer should take the time to explain the concepts of underseepage and the consequences of a hydrofracture on the underseepage regime to the owner and drilling contractor. This interaction will help the owner and driller buy in to the technical requirements.

\section{Recommendations}

The District has successfully allowed fiber-optic cables to be installed under existing flood protection levees using HDD techniques. This has been done without hydrofracturing the foundation and without creating preferred seepage paths along the installed casing. During the design phase, the District learned that the Corps of Engineers lacked geotechnical engineers who are experienced 
in this particular field. The District also learned that the USACE has no technical guidelines in place to control these installations. The recommendation is that the USACE should develop technical guidance to direct the design and construction of future HDD installations.

The authors of this report, working under the general guidance of the Geotechnical Engineering Research Program, have proposed guidelines, "Guidelines for Installation of Utilities Beneath Corps of Engineers Levees Using Horizontal Directional Drilling" (Latorre, Conroy, and Wakeley, technical report in preparation). After publication, this report may be found at

http://libweb.wes.army.mil/index.htm. 


\section{References}

American Association of State Highway and Transportation Officials. AASHTO HS-20, Washington, DC.

American Fiber Comm. (2000). "Mississippi River bore, mile 182.7, permit application," prepared by Sheppard, Morgan, and Schwabb, Inc., Consulting Engineers, Alton, IL.

American Society for Testing and Materials. "Annual Book of Standards," Philadephia, PA.

a. Designation: ASTM D-698. (1991) (Reapproved 1998). "Standard Test Method for Laboratory Compaction Characteristics of Soils Using Standard Effort."

b. Designation: ASTM D-2487. (1998). "Standard Practice for Classification of Soils for Engineering Purposes (Unified Soil Classification System).”

c. Designation: ASTM D-2922. (1996). "Standard Test Method for Density of Soil and Soil-Aggregate in Place by Nuclear Methods."

d. Designation: ASTM D-3017. (1996). "Standard Test Method for Water Content of Soil and Rock in Place by Nuclear Methods."

Latorre, Carlos A., Wakeley, Lillian D., and Conroy, Patrick J. "Guidelines for installation of utilities beneath Corps of Engineers levees using horizontal direction drilling" (technical report in preparation), U.S. Army Engineer Research and Development Center, Vicksburg, MS.

Pipeline Research Council International. (1995). "Installation of pipelines by horizontal drilling-An engineering guide," Contract No. PR-227-9424, J. D. Hair and Associates, Tulsa, OK, Louis J. Capozzoli, Inc., Baton Rouge, LA, and Stress Engineering Services, Inc., Houston, TX.

Staheli, Kimberlie, Bennett, David, O’Donnell, Hugh W., and Hurley, Timothy J. (1998). "Installation of pipelines beneath levees using horizontal directional drilling," Technical Report CPAR-GL-98-1, U.S. Army Engineer Waterways Experiment Station, Vicksburg, MS. 
Williams Communications Co. (2000). "Fiber optic communications system Cahokia Creek Diversion Channel Crossing, Hartford, IL," prepared by Burns and McDonnell Engineers-Architects-Consultants, Kansas City, MO. 


\section{Bibliography}

Khan, Salam, Bennett, David, McCrary, Steven, and Iseley, Thomas. (1994). "Mini-horizontal directional drilling," U.S. Army Engineer Waterways Experiment Station, Vicksburg, MS, and Trenchless Technology Center Louisiana Tech University, Ruston, LA.

Sills, George L. (1999). "Cumulative effects of sand boils," U.S. Army Engineer District, New Orleans, New Orleans, LA. 


\section{Appendix A American Fiber Comm Mississippi River Bore Special Conditions}




\section{AMERICAN FIBER COMM MISSISSIPPI RIVER BORE SPECIAL CONDITIONS}

\section{SUBMITTALS}

1. All submittals will be made to American Fiber Comm at the following address within twenty-one (21) days after completion of casing pullback:

American Fiber Comm

P. O. Box 898

Edwardsville, IL 62025

Attn: James T. Mihalich, Project Manager

These include:

a. Copies of the laboratory and field testing reports from a certified testing laboratory including soil classification, ASTM D 2487; laboratory moisture density relationship, ASTM D 0698; and in-place moisture and density, ASTM D 2922 and D $3017 .{ }^{1}$

b. As constructed profile drawing on the HDD bore.

c. Report of drill stem and external pressures.

\section{DEPTHS OF COVER}

1. The Conduit System shall be placed with a minimum cover of forty-two inches (42") except where:
a. Otherwise specified in the Drawings;
b. Accepted by Contractor;
c. Governing authorities or ROW owners dictate a greater depth;
d. Required to be eight inches (8") below the frost line; or
e. Where greater Conduit System depth will be required at the following locations:

2. At road crossings, the Conduit System shall be placed with a minimum cover of forty-eight inches (48") below the top of pavement.

3. In drainage ditches, the Conduit System shall be placed with a minimum cover of forty-two inches (42") below the clean out elevation; unless the

\footnotetext{
${ }^{1}$ References cited in Appendix A are listed in References section following main text.
} 
controlling authority requires additional depth in which case the greatest depth will be maintained.

4. Where the Conduit System crosses railroads, the Conduit System shall be placed at a minimum depth of sixty inches (60") below the base of rail or sixty inches (60") below the paralleling drainage ditches, whichever is greater.

5. Where the Conduit System crosses Existing Facilities, including pipes, cables, or other structures, the Conduit System will be placed to maintain a minimum of twelve inches (12") clearance under the Existing Facility or a minimum clearance as required by the governing authorities or facility owner, whichever is greater. In the event that the top of sub-surface Existing Facility is greater than seventy-two inches (72") below grade, the Conduit System may be placed over the object while maintaining the twelve inch (12") clearance if such action is not in conflict with permits and in accordance with the requirements of governing authorities and ROW owners. In all cases, the Conduit System shall be placed a minimum of forty-two inches (42") below grade.

6. Unless otherwise specified, where the Conduit System crosses gullies, ditches, streams, rivers, creeks, canals, and washes, the Conduit System will be placed at a minimum cover of forty-eight inches (48") below the bottom of the waterway unless the controlling authority requires additional depth in which case the greatest depth will be maintained. In navigable waterways, or levee crossings, the Conduit System shall be placed a minimum of thirty-five feet (35') below the bottom of the waterway, or as detailed on the Drawings or directed by the Contractor.

\section{MATERIALS}

\section{General.}

a. Subcontractor shall furnish all materials not otherwise furnished by the Contractor necessary to complete the Work. Materials shall be new and complete in all respects. Subcontractor shall assume full responsibility for ordering materials of the quality specified, and in the quantity necessary, and shall be responsible for the timely delivery of all materials. Major materials to be furnished by Subcontractor shall conform to the respective Specifications.

b. Multiple ducts to be installed shall be color coded as follows:

- Each duct shall have a different color.

- Colors shall be orange, yellow, black, white, red, green, blue, gray, lilac, buff, brown and pipe green.

- Subcontractor shall assure that the duct reels contain the following color arrangement:

- One reel red and green

- One reel blue and gray

- One reel lilac and buff 
- One reel brown and pipe green

- One reel orange and yellow

- One reel black and white

Subcontractor shall install orange and yellow and black and white ducts on the bottom. Placement of other colors shall be provided by the Contractor based on the number of ducts to install and arrangement of them. See Section 18 for arrangement of ducts in handholes and manholes.

c. The duct shall be supplied on ninety-six inch (96") reels containing two colors of thirty-six hundred feet (3600') each.

2. Duct and Pipe. Piping materials will be as outlined below, unless otherwise specified in the Drawings.

a. Steel

- Black iron steel pipe shall be resistance welded or seamless, structural grade, with an average minimum wall thickness of $0.250 "$, single random length pipe, plain end.

- Cathodic protection shall be provided for steel casings at locations where grounding is required in the vicinity of high voltage power transmission towers, electric transit systems, catenary wires, or underground power cables.

b. HDPE

- Pipe shall be smooth wall SDR 9 or 11 , high-density polyethylene (HDPE), color as specified, and manufactured in accordance with standards established by the Plastic Pipe Institute and shall be furnished without pull rope unless otherwise specified.

- Subcontractor shall use SDR 11, except Subcontractor shall install SDR 9 where indicated in other Specification Sections and on the Drawings.

c. Pipe Plugs

- Vacant pipes shall be sealed with solid duct plugs. Contractor predetermined materials, duct plugs and simplex split cable plugs will be furnished by Subcontractor.

- Plugs for multicell duct shall be provided by the duct manufacturer.

- Voids between the pipe and core bores shall be sealed with "Model CSL Linx" mechanical seal as manufactured by Calpico. Building vault seals shall use stainless steel bolts, nuts, washers, and pressure plates, and shall be capable of developing a hydrostatic seal of up to forty feet (40') of head. 


\section{d. Sealing Foam}

- Sealing foam shall be expanding, non-degradable urethane foam, with a density of 1.75 .

e. Buried Warning Tape

- Cable warning tape for burial shall be three inch (3") wide 6 mil. Super stretch marker tape in 6,000 foot rolls. It shall be imprinted custom black on orange virgin polyethylene tape with three inch (3") diameter PVC cores. The imprinted image shall be repeated approximately every twenty-three inches (23") as shown in the Drawings.

3. Concrete Materials.
a. Concrete

- 3,500 psi compressive strength at 28 days of age.

- Air-entrained with slump between 1 and 4 inches.

- Minimum 6 sacks of cement per cubic yard.

b. Grout

- 6 to 7 gallons of water per sack of Type I Portland Cement. Add 5 percent $(5 \%)$ bentonite by weight of cement to retard shrinkage and provide plasticity.

4. $\quad$ Drilling Mud.

a. In addition to other applicable specifications, Subcontractor shall provide all labor, equipment, supplies, materials (unless otherwise provided), and supervision to furnish and install the Work herein specified, as applicable.

b. This specification is to be utilized in conjunction with other applicable specifications and Subcontract Documents.

c. The directional boring subcontractor shall submit details of the bentonite hydration, circulation and de-sanding operations prior to mobilization.

d. Mud viscosity shall be 50-60.

\section{GENERAL REQUIREMENTS FOR PIPE}

1. Description.

a. In addition to other applicable specifications, Subcontractor shall provide all labor, equipment, supplies, materials (unless otherwise 
provided), and supervision to furnish and install the Work herein specified, as applicable.

b. This specifications is to be utilized in conjunction with other applicable specifications and Subcontract Documents.

\section{Requirements for Pipe.}

a. Subcontractor shall transport all pipe to the site of the Work. All pipe materials shall be properly handled and stored. Reels shall be placed on a level area and securely blocked to prevent accidental movement.

b. Defective pipe shall not be installed and shall be removed immediately from the site of the Work.

\section{Pipe Jointing.}

a. Pipe jointing shall be completed as the material is installed. Pipes indicated to be occupied by FOC, including spares for future FOC use, shall have joints capable of withstanding two hundred (200) p.s.i. air pressure for installing pull line or blowing FOC. Pipe joints shall be as specified below:

- Black Steel: The pipe ends shall be plain ended. Steel casing pipe shall be full circle welded and the inside of the pipe shall be free of burrs and weld slag.

- HDPE: The duct pipe shall be spliced together with Contractor predetermined materials, using equipment recommended by the manufacturer. Where pipe is or may be occupied by FOC, joining by the butt fusion method shall not be allowed. HDPE casing pipe shall be joined by the butt fusion method using the duct manufacturer's recommended equipment.

\section{Pipe Testing and Cleaning.}

a. When pipe is installed, it shall be proofed by testing and clearing before acceptance. As a test, the duct shall pass a solid aluminum or steel mandrel or a pig with a minimum length of four inches (4") and a one inch (1") diameter. The mandrel or pig shall be accepted by Contractor prior to proofing any duct. All foreign material, earth, sand, and gravel shall be removed from the pipes. Pipes that will not be immediately used shall be tested and plugged at each end.

b. The Contractor must be informed at least forty-eight (48) hours prior to the start of any proofing operation. At the discretion of the Contractor, Contractor shall have an opportunity to witness part or all of the proofing operations. Pipe that is proofed without the advance knowledge of Contractor shall be considered incomplete. Failure to 
obtain written approval and/or observation may result in Subcontractor being required to reproof.

\section{RIGHT-OF-WAY PREPARATION}

1. Description. This section describes the Work associated with ROW preparation and consists of the clearing and grubbing of brush, tree limbs, trees, stumps, and incidental debris from the Conduit System alignment.

\section{2. $\quad$ Clearing.}

a. Subcontractor shall remove and dispose of trees and/or brush within the path of the Network as required by the route drawings. All clearing shall conform to the laws, rules and regulations of all authorities having jurisdiction of the ROW. Subcontractor shall clear cut all brush and trees to create a clean path for construction and at a width of no less than five feet $\left(5^{\prime}\right)$ on each side of the Network running line. When cleared, trees, brush and stumps shall not protrude from the ground greater than two inches (2").

b. Where required by governing authorities or ROW owners, landscaped, decorated, ornamental trees, or any tree over six inches (6") in diameter shall be preserved and protected.

3. Waste Disposal. Tree tops, tree trimmings, slashing, branches, brush, stumps and other debris shall be chipped and removed from the ROW and disposed of in a manner satisfactory to the Contractor. Chipped material shall not be left in proximity to railways or roadways. Chipped material shall be removed from MESD and City of St. Louis Levee District ROW. Debris shall not be burned without a permit, or buried or pushed off the cleared ROW and left on adjoining areas, or shoved into piles either separately or with earth from grading. Debris shall be completely disposed of ahead of the Conduit System installation.

4. Temporary Construction.

a. Where it is necessary to remove existing fences at Conduit System crossings and along the ingress and egress routes, temporary fences or gates shall be installed immediately. All fences shall be "H" braced before being cut. Temporary fences or gates shall be provided with suitable materials and fasteners of a type and character equivalent to the existing fence, and shall be kept closed at all times except when necessary to be opened for construction purposes. Existing fencing so removed shall be replaced in kind as the Conduit System installation is completed.

b. Temporary construction, including, but not limited to, bridges, roadways, and ramps, may be constructed as required to provide for the passage of equipment necessary for construction operations. Any temporary conditions on MESD ROW, City of St. Louis ROW, or Corps ROW shall 
be preceded by written permission for this work from the representative agency. Subcontractor shall furnish any materials required for this purpose. Forging streams shall be prohibited unless specifically provided for in the Subcontract Documents. Any such temporary construction shall be removed as the Conduit System installation is completed.

\section{Grading.}

a. Grading shall be held to the absolute minimum required to perform the Work.

b. Irregularities in the ROW shall be graded preceding the Conduit System installation to permit the Conduit System to be correctly installed.

c. Subcontractor shall grade the ROW such that no sharp over-bends or sag bends will be required when the Conduit System is constructed. Grading shall be performed to ensure that the Conduit System vertical and horizontal alignment is smooth and uniform and required depths are maintained while minimizing environmental damage.

d. Where large rocks, fill, or other such materials have been placed over the Conduit System alignment, Subcontractor shall remove the materials to expose natural ground surface.

\section{DUCT PLACEMENT}

1. Description. This section covers the installation of duct. Subcontractor shall provide all equipment and tools for pulling the duct.

\section{Duct Placement.}

a. All ducts being placed in a casing shall be pulled in simultaneously. Innerducts shall be of one (1) continuous length between pull points unless intermediate splice points are otherwise accepted by the Contractor, and if Contractor approved when pulling multiple innerducts that have been spliced, the splices shall be staggered. After FOC has been installed, the orange innerduct on each side of a handhole or manhole shall be plugged with Jackmoon simplex plugs.

b. The pulling force on the innerduct shall not exceed 3,000 psi.

c. On completion of duct placing, the innerduct shall rest freely in casing without tension. Sealing and racking of the duct in manholes shall be completed after the cable is placed and as a part of cable placing.

d. The ducts shall enter and leave manholes and handholes exactly opposite each other within the manhole or handhole to facilitate the cable coils and/or splice closures. Each duct length inside manholes and handholes shall be a minimum length of eighteen inches (18"). 
e. Duct shall have a gradual sweep into the manholes and handholes if the depth of duct bury exceeds forty-eight inches (48").

f. Prior to duct placement in the trench, the multiple duct shall be bundled, tied and/or bound by an accepted method to eliminate the possibility of the duct twisting and/or waving in the trench.

3. Duct Splicing. Duct ends shall be cut square to provide flush-butting surfaces when spliced. The inside edge shall be free of burrs that could impede the cable installation operations. Duct splicing shall be accomplished only by the utilization of Contractor predetermined materials furnished by Luzon or owner/approved substitutions.

\section{BORE OPERATIONS}

\section{Description.}

a. This section covers pushing, boring, or simultaneously boring and pushing casing pipes and duct under roads, exit ramps railroad tracks, driveways, sidewalks, trees, environmental sensitive areas and other features as indicated on the Drawings or as directed by the Contractor.

b. This section specifies conventional horizontal boring, directional/guided bores, rock bores, and long directional bores with use of drilling mud.

c. All boring Work performed shall be in accordance with laws, permits and the requirements of governing authorities and ROW owner.

d. Provide an inspector, independent of the boring contractor, to observe and document the construction.

e. All pressure gauges and sensors shall have been calibrated within the previous six (6) months, using standards traceable to NIST.

2. Material Requirements. The material for boring shall be a ten (10) innerduct encased in one (1) ten inch (10") 0.250 wall steel pipe for rock bores or soil bores as shown on the Drawings.

3. Pipe Placement - Bore Method.

a. Acceptable boring installation methods is horizontal direction drilling.

b. Casing pipes shall be bored in place at locations as indicated on the Drawings as directed by Contractor.

c. All bores shall be cased in steel pipe. SDR 11 duct shall be placed in the casing.

d. Adequate barricades shall be erected to limit access to the boring machine to operating personnel only. 
e. Subcontractor shall calibrate the boring head locator at the start of the day and at each new boring operation. A daily calibration log shall be established and maintained for Contractor review and submitted for final record. At a minimum, calibration shall include readings at the 3, 6, 9 and 12 o'clock positions with the locator in the housing that it will be installed in during the drilling and on a level surface. The calibration should also be performed with the locator at the neutral positions and set at a fifteen degree $\left(15^{\circ}\right)$ pitch.

f. Before boring, all clearances shall be checked by Subcontractor. All Existing Facilities shall be located and marked or exposed as necessary for safety and for protection of the existing facility.

g. Boring machines shall be grounded at all times during operation. The grounding method and operator's safety practices shall comply with the manufacturer's guidelines and requirements.

h. The installation of the casing shall be performed in a manner that will not disrupt traffic nor damage the subgrade, and will provide accurate alignment and grade of the casing pipe. Removal of material from an augured hole by washing will not be permitted. Small amounts of water may be used as a lubricant in the boring or jacking operation.

i. Water slurry for mini-directional boring may only be used for head lubrication and spoils return. The use of wet bores or jetting by using high-pressure liquids or large liquid volume boring is not an acceptable method of boring.

j. The boring operator shall have full control of the direction of the boring tool at all times. Shallow, misdirected or other unsuccessful bores shall be abandoned and filled at the direction of Contractor at Subcontractor's expense. If a bore cannot be completed but has to be abandoned under City of St. Louis or MESD levees, any and all voids shall be completely grouted shut with a cement-bentonite grout.

k. Under no circumstances will Subcontractor be allowed to cut or disturb pavement, asphalt, railroad ballast, or other Existing Facilities, or excavate within the relative limits of any roadway or railway surface to retrieve any lost boring apparatus.

I. $\quad$ Bore pull back reamers shall be a minimum of two inches (2") greater than the diameter of the casing. Fluted reamers shall be used. Packer reamers are not permitted.

m. The maximum entry bore angle shall be fifteen (15) degrees as measured from grade at the bore entry to the deepest bore elevation.

n. Bore pits shall be no less than fifteen feet (15') from the edge of a public road; no less than five feet ( $\left.5^{\prime}\right)$ from the edge of a driveway; no less than thirty feet (30') from railroad tracks, and will conform to the 
requirements of governing authorities and ROW owners or as required by the Drawings. Bore pits shall be located a minimum distance of three hundred feet (300') from the landward toe of an existing levee or as shown on the Drawings.

o. If the bore exits below the prescribed depth, the Subcontractor shall take measures to gradually return the bore depth to the prescribed depth.

p. $\quad$ All bore pits shall be backfilled and compacted in eight inch (8") loose lifts using soils classified as silt or clay (ML, CH, CL) in accordance with ASTM D 2487. Compact with sheepsfoot trench compactor or other approved mechanical means to a dry density greater than ninety-five percent (95\%) of ASTM D 698 maximum density within a moisture range of three percent $(3 \%)$ below to three percent $(3 \%)$ above the corresponding optimum moisture content. Wheel-tracking or bucket tamping are not acceptable compaction methods. Surfaces shall be restored to original or better condition and to the satisfaction of Contractor, governing authorities, and ROW owners.

q. When trenching is required from a bore pit to the end of plowing or trenching operations, prior to innerduct placement in the trench, the innerduct shall be bundled, tied and or bound by an accepted method to eliminate the possibility of the innerduct twisting and or waving in the trench.

r. The boring Subcontractor shall be responsible for proofing the bored duct installed. Tie-ins are the responsibility of the Subcontractor making the tie-in.

s. Mud-motor techniques shall be used at levee crossings. Auguring or jacking methods shall not be used at levee crossings.

4. Rock Identification - Bores.

a. If after two (2) unsuccessful attempts by Subcontractor to bore with soil boring machines due to the possibility of rocks or other obstructions, then the Contractor shall determine if rock conditions exist by:

b. Prior to additional boring, excavations indicate the existence of ledge rock.

c. Determining that "Hard Rock" exists if the unconfined compressive strength of the rock is 10,000 psi and higher and where a minimum of 50,000 pound rock-boring machines are used in combination with mud motors or special rock bits. If Contractor or Subcontractor cannot agree on the hardness of the rock, Subcontractor shall provide a core sample and shall have the sample tested. If the test shows that the sample rock has a compressive strength of less than 10,000 psi or more, 
Contractor shall pay for the coring and testing costs. See Article E, Section 31 (g) and (h).

d. Determining that "Rock" exists if it is greater than 3,000 psi but less than 10,000 psi rock including shot rock and concrete roadway fill, where a minimum of 50,000 pound rock-boring machines are used in combination with mud motors or special rock bits.

e. All other bores shall be considered soil bores.

\section{Railroad Boring Restrictions.}

a. When directional bore methods are used, the bore depth with steel casing shall be a minimum of five feet ( $5^{\prime}$ ) below base of rail and five feet $\left(5^{\prime}\right)$ below natural ground. For depths greater than ten feet (10') below base of rail and five feet ( $\left.5^{\prime}\right)$ below natural ground, a single HDPE SDR 11 casing may be used in lieu of a steel casing. Approved minidirectional wet bores shall be installed a minimum depth of ten feet (10') below the toe of ballast section and a minimum of five feet $\left(5^{\prime}\right)$ below natural ground line.

b. Subcontractor shall not excavate into the side slopes of raised track beds. Backfill for excavations shall be mechanically tamped in six inch (6") lifts to same density as adjoining earth, and as otherwise specified.

c. Steel casing shall be installed to a minimum of thirty feet (30') from the track centerline of each side of the track.

d. On railroads, bore locations shall be greater than one hundred feet $(100$ ') from bridges or culverts and fifty feet $(50$ ') from the nearest switch.

e. Bore pits shall be a minimum of thirty feet (30') from the centerline of the track and never located in the slope, cut or fill section of the roadbed.

f. Blasting shall not be allowed.

6. Long Directional Bores.

a. When long boring requires the use of drilling mud, such as bentonite, no discharge or runoff will be allowed into waterways. Mud tank capacities shall be sized to hold excess material without spillage. The casing pipe entry point shall be appropriately enclosed and equipped with a sump pump to reclaim or discharge excess mud to a reuse or disposal tank. Earth spoiled by drilling mud shall be removed and disposed of by Subcontractor and the site refilled with clean material. The site shall be restored to a condition equal to or better than its original condition. Excavations within fifty feet (50') of the riverside levee toe and three hundred feet $\left(300^{\prime}\right)$ of the landside levee toe shall be backfilled per the 
requirements of sub-item ' $p$ ' in the section entitled "Pipe Placement Bore Method."

b. Sufficient personnel, equipment, and materials to contain drilling fluid that upwells to the surface or is discharged into a body of water shall be onsite during all drilling operations.

c. Subcontractor shall maintain a record of the drilling pressures for the initial pilot hole in the annular space outside the drill stem and the quantities of drilling fluid used during the entire boring operation. This record shall be tied to both time of day and station of the bore head. These records shall be made available to the Contractor at all times during the drilling operations and submitted as record at the conclusion of the operation.

d. Subcontractor shall maintain continuous visual inspection of the bore alignment at all times when the bore operation is proceeding without return of drilling fluid to the drill site. When the bore alignment is beneath a body of water, a visual inspection shall be made at the most accessible point immediately downstream of the bore alignment for changes in turbidity or color, which may indicate a fluid discharge into the waterway. Unusual conditions, including excessive loss of drilling fluid, shall be reported promptly to the Contractor.

e. Drilling fluids shall be disposed of in an acceptable manner.

f. Foundation damage caused by hydro-fracture or inadvertent returns within the critical areas adjacent to levees shall be repaired to the satisfaction of the MESD Levee District and the Corps of Engineers. The critical areas are within fifty feet $\left(50^{\prime}\right)$ of the riverside levee toe and three hundred feet (300') of the landside levee toe on both sides of the river.

g. Monitor the external pressure of the drilling fluid in the annular space outside the drill stem. Use the pressure sensing device manufactured by ENSCO and distributed by Sharewell. Locate device one foot (1') behind the bit assembly.

h. Control the drilling operation so that the external pressure of the drilling fluid in the annular space outside the drill stem is less than the allowable pressures below: 


\section{Allowable Maximum External Pressures}

\begin{tabular}{|c|c|c|}
\hline Depth (ft.) & MO Entrance (psi) & IL Exit (psi) \\
\hline 5 & 15 & 13 \\
\hline 10 & 42 & 36 \\
\hline 15 & 20 & 59 \\
\hline 20 & 62 & 24 \\
\hline 25 & 111 & 122 \\
\hline 30 & 128 & 140 \\
\hline 35 & 138 & 177 \\
\hline 40 & 148 & 188 \\
\hline 45 & 158 & 198 \\
\hline 50 & 168 & 217 \\
\hline 55 & 177 & 223 \\
\hline 60 & 186 & 228 \\
\hline 65 & 195 & 237 \\
\hline 70 & 204 & 246 \\
\hline 75 & bedrock (72') & 256 \\
\hline 80 & & 265 \\
\hline 85 & & 273 \\
\hline 90 & & 282 \\
\hline 95 & & 291 \\
\hline 100 & & 300 \\
\hline 105 & & bedrock \\
\hline & & \\
\hline
\end{tabular}

i. Record the drill stem pressure (at the pump) and the external pressure in the annular space at one foot (1') increments of depth in unconsolidated soil, five foot $\left(5^{\prime}\right)$ increments in rock for the first one hundred feet $\left(100^{\prime}\right)$, increasing to fifteen foot $\left(15^{\prime}\right)$ increments thereafter. Provide a report of this data.

j. Upon completion of reaming and pull back, grout the annular space between the bore and the steel casing for a minimum length of one hundred feet (100') from the entrance of the casing into the handhole. Stage grout from the back of the pipe. Withdraw pipe at a rate to maintain the nozzle buried within the grout mass.

\section{COMMON EXCAVATION}

1. General. This specification describes common excavation work necessary to install the Conduit System, including those excavations necessary to set manholes, handholes, bore pits, and other miscellaneous excavations required throughout performance of the work.

2. Trench Excavation.

a. During trench excavations, materials suitable for backfilling shall be stockpiled in an orderly manner a sufficient distance from the banks of the trench to avoid overloading and to prevent slides or cave-ins. All 
material not suitable for backfill shall be removed and disposed of properly.

b. Wherever possible, the trench shall be excavated to permit the Conduit System to rest on undisturbed earth. Care shall be taken not to excavate below the depths indicated. Unauthorized over-excavation shall be backfilled with suitable bedding material and thoroughly compacted. Care shall be taken not to exceed the limits imposed by governing authorities, ROW owners, or permit requirements.

c. No unprotected open trench shall be allowed to remain at the end of the workday in public or private ROW. Trenches left open overnight or unattended shall be fenced or barricaded in accordance with the requirements of governing authorities and ROW owner and accepted by the Contractor. A trench shall not remain open overnight on railroad ROW unless approved in writing by the railroad representative on a site and date specific basis. Any open trench not backfilled may be covered as accepted by Contractor in accordance with these specifications, Article A and the governing authorities' or ROW owners' rules and regulations.

d. Driveways, lanes, or roadways, which are open cut, shall be opened just prior to the duct placement. In no case shall the driveway, lane, or roadway be left impassable at the end of the day.

e. The Conduit System trench line shall be as straight as practicable, following the staked alignment. The bottom of the trench shall be smooth and free from any sharp edges. The trench shall be kept clear of debris and loose rock. All changes in trench grade shall be gradual and accepted by the Contractor. In general the vertical change in grade shall not exceed one foot (1') for every three feet (3') in length (1:3).

f. Slope handholes and trench excavations at an inclination of 1:1 or flatter as required by OSHA or soil conditions to facilitate proper backfill compaction and to prevent development of tension cracks near the surface soils.

g. The trench shall be sloped back to facilitate compaction and to prevent sloughing or cracking in the sidewalls or trench excavations within the critical area (300 feet landward of the landside levee toe and 50 feet riverward of the riverside levee toe) or in other critical areas defined on the Drawings.

h. The Subcontractor shall have an adequate volume of suitable backfill materials to fill in excavations located within the critical area in the event of potential flooding. 


\section{Sheeting and Shoring.}

a. Subcontractor shall comply with all current and applicable Occupational Safety and Health Administration (OSHA), federal, state, and local rules and regulations governing the safety of men and materials during excavation, installation, and backfilling operations.

b. Banks of trenches shall be properly shored and braced as may be necessary to facilitate excavation and to prevent caving, and to protect the workmen, adjacent property, and Existing Facilities. In areas where unstable material is encountered, shoring or sheeting may be required to prevent lateral movement of material into the excavation. Sheeting, bracing, and shoring shall be designed and built to withstand all loads that might be caused by earth movement or pressure, and shall maintain the shape of the excavation under all circumstances.

\section{Hand Trenching.}

a. Hand trenching shall be performed to place the Conduit System under, over, or adjacent to Existing Facilities.

b. Handwork to grade the trench bottom, hand digging of test pits to expose Existing Facilities and to verify utility locations, and sections of handwork combined with careful backhoe excavation shall not be considered as hand trenching.

c. Unless otherwise designated, the Conduit System shall be placed below all Existing Facilities, which are encountered except when the Existing Facilities are at a depth greater than seventy-two inches (72") per Section 1. Clearances, both vertical and horizontal, shall be as indicated on the Drawings or as required by governing authorities and ROW owners.

\section{Trench Width.}

a. All trenches shall be wide enough to provide ample room for proper installation of the Conduit System.

b. Where it is necessary to reduce the earth load on trench banks to prevent sliding or caving, trench banks may be cut back on slopes which shall not extend lower than twelve inches (12") above the top of the Conduit System.

6. Subgrade Preparation and Stabilization. Subgrade for manholes and handholes shall be firm and free from all loose materials, shall be free from mud and muck, and shall be sufficiently stable to remain firm and intact. 
7. Subsurface Groundwater, Dewatering.

a. When groundwater is encountered in excavations, Subcontractors shall dewater as required to provide for stability and firmness. Dewatering shall be performed as needed for placement, inspections, measurements, and backfilling operations before and during installation of the work.

b. If dewatering is required for excavations made in the critical area, the appropriate St. Louis District, of the U.S. Army Corps of Engineers shall be notified prior to the commencement of dewatering operations.

$$
\text { St. Louis District: } \quad \text { Pat Conroy (314) 331-8432 }
$$

\section{BACKFILLING AND COMPACTION}

1. Description. This section specifies the work of backfilling and compacting excavations necessary to install the FOC System. Backfill, compaction, compaction testing, and surface treatments will not be measured for payment. They will be considered incidental to other elements of the work.

\section{General.}

a. All excavations shall be backfilled at the end of each working day, except as otherwise authorized by the Contractor, governing authorities, and ROW owner. Where applicable, backfill shall be compacted and shaped to the original contour and drainage. Backfill and compaction shall be performed with extreme care so as not to damage the FOC System.

b. On finished areas including road surfaces, road shoulders, parking areas, lawns, and public ROW, backfill and compaction shall be in accordance with the governing authority and ROW owner having jurisdiction thereof, and in accordance with these Specifications or as indicated on the Drawings. In the event of a conflict between these Specifications or the Drawings, and the requirements of governing authorities or ROW owners, the more stringent requirements shall apply.

\section{Earth Backfill.}

a. Excavations within the critical area (300 feet landward of the landside levee toe and 50 feet riverward of the riverside levee toe) or at other critical areas defined on the Drawings, shall be completely backfilled to the original ground surface and compacted with suitable material. Suitable materials consist of silt $(\mathrm{ML})$ and clay $(\mathrm{CL} / \mathrm{CH})$ as defined in ASTM D 2487. Granular bedding shall not be used as backfill in the critical area. 
b. Material for backfill shall be as accepted by Contractor and composed of suitable materials only and shall not contain unsuitable material, including, but not limited to, logs, stumps, frozen material, wood, grass, roots, broken concrete, boulders, trash, organic material, other debris or rocks greater than two inches (2") in diameter. Borrow material shall be obtained from approved off-site sources. Borrow material for backfill shall not be obtained from within the critical area.

c. All backfill material shall consist of loose earth having moisture content such that the required density of the compacted soil will be obtained with the compaction method used. Moisture content shall be distributed uniformly. Water for correction of moisture content shall be added sufficiently in advance so that proper moisture distribution and compaction will be obtained.

d. If rocks are removed from any backfill material, Subcontractor shall remove such rock and unused spoil from the rights-of-way. Subcontractor may dispose of the rock on the ROW with written approval of governing authorities or ROW owners.

e. Rock will not be permitted in the backfill where it may interfere with plowing and cultivation, or the passage of farm vehicles and livestock. In this event, rock free soil shall be used to fill the excavation.

f. The Conduit System, whether installed in common excavation or rock excavation, shall be covered by an initial layer of selected backfill. In common excavations, the Conduit System shall be covered with a four inch (4") selected backfill. In rock excavation, in addition to a four inch (4") layer covering the Conduit System, two inches (2") of select backfill shall be placed beneath the Conduit System.

g. Well graded backfill with rock less than two inches (2") maximum dimension may be placed in excavations on top of the select backfill provided that enough smaller graded material is also used to allow complete compaction of the trench without damaging the Conduit System. If rock areas are within public rights-of-way, Subcontractor shall provide select backfill material to satisfy the backfill compaction requirements of the governing authority having jurisdiction thereof.

h. On a case by case basis with Contractor approval, after placement of the handhole and completion of any concrete or grout work at a splice location, Subcontractor may backfill to a level even with the top of the handhole with the excavation being left in the above condition until after fiber placement and splice completion. After the splice is completed, the Subcontractor shall complete the backfill of handhole pit in accordance with the Drawings. 


\section{Compaction.}

a. Place backfill in eight inch (8") lifts. Where hand compaction techniques are to be used, backfill shall be placed in four inch (4") lifts.

b. Backfill shall be compacted to meet the following conditions:

- Compact backfill to a minimum of ninety-five percent (95\%) of maximum density in accordance with ASTM D 698, within a moisture content range of three percent $(3 \%)$ below to three percent $(3 \%)$ above the corresponding optimum moisture content.

c. Each lift shall be mechanically compacted with a sheepsfoot trench compactor or other approved equipment. Subcontractor's method of placing and compacting the backfill shall be subject to the Contractor's review and approval, and be performed with equipment suitable for the intended purpose. Wheel-rolling and bucket tamping are not acceptable compaction methods. Contractor's review and approval shall not relieve Subcontractor of full responsibility for meeting compaction requirements. Contractor may request adjustments to the procedure depending on changes in soil types and other conditions such as moisture content. Particular care shall be taken to compact backfill that will be beneath or adjacent to pipes, drives, roads, or other Existing Facilities.

d. All excavations that have not been acceptably backfilled and compacted, or which settle after backfilling, shall be removed and replaced or otherwise corrected in accordance with these specifications.

e. Subcontractor shall install specified warning tape a minimum of one foot (1') below grade.

f. When an excavation is located under paved surfaces, cold-mix patch shall be placed as a temporary surface restoration as soon as possible after the completion of backfill compaction if permanent paving will not occur with one (1) week, or as otherwise required by governing authorities and ROW owners.

5. Compaction Testing.

a. Backfill compaction and moisture content testing shall be conducted at a frequency of one (1) test per lift per one hundred feet (100') of trench excavation and backfill in critical areas. Testing at a frequency of one (1) per lift shall also be conducted at all handhole locations within critical areas.

b. Test methods

- Soil Classification - ASTM D 2487

- Laboratory Moisture Density Relationship - ASTM D 698 
- In-Place Moisture and Density - ASTM D 2922 and D 3017

\section{MANHOLE AND HANDHOLE PLACEMENT}

1. Description. This section covers the installation of manholes and handholes for housing FOC System.

2. Material Requirements.

a. Handholes shall be forty-eight inch (48") diameter handholes as shown in the Drawings. Handholes shall be provided with a polymer concrete frame and cover when specified to be buried and provided with a cast iron frame and cover when specified to be exposed. Polymer concrete covers shall have an EMS marker embedded within the cover. Polymer concrete covers shall be load rated to 20,000 pounds with a non-skid surface and be secured by hex head bolts. Cast iron frame and covers shall have an AASHTO HS-20 load rated surcharge in addition to normal soil pressure.

b. Where handholes and manholes are placed in roadways, they shall have a AASHTO HS-20 load rated surcharge in addition to normal soil pressure. Handhole placement between fifteen feet (15') and twentyfive feet $\left(25^{\prime}\right)$ from the centerline of railroad tracks shall be AASHTO HS-20 loaded.

c. When handholes and manholes are placed within fifteen feet (15') of a railroad track centerline, they shall be load rated for a Cooper E-80 surcharge in addition to normal soil pressure.

3. Handhole and Manhole Placement.

a. Handholes shall be placed at the end of duct reels, approximately every three thousand six hundred feet $\left(3,600^{\prime}\right)$ for HDPE ducts and one thousand five hundred feet $(1,500$ ') for PVC duct. Handholes shall be located on one (1) side of every bore location except if the pay length of the bore is less than one hundred feet $\left(100^{\prime}\right)$ and the bore is closer than two thousand feet $\left(2,000^{\prime}\right)$ from another handhole. Handholes shall be placed on one (1) side of each bridge attachment.

b. Subcontractor shall install handholes at locations as shown on the Drawings and as directed by Contractor. Handholes shall not be placed within fifteen feet $\left(15^{\prime}\right)$ from the edge of roadway pavements or within thirty feet (30') from the centerline of railroad tracks without prior written authorization.

c. Handholes located within the critical area shall be set on a concrete pad which shall encase the HDPE or steel casing pipe as shown on the Modified Handhole Detail for Critical Areas Detail. Each handhole shall be installed prior to placing cable. The Contractor is responsible for 
coordinating the grouting and concrete placement requirements with the handhole placement.

d. Minimum cover for handholes shall be six inches (6") and a maximum of twelve inches (12") below finished grade. A marker shall be placed to mark the location. At all splice manhole locations, a locate-system box shall be installed in close proximity to the splice handhole. The size of the locate-system box shall be twelve inches (12") by twelve inches (12") by twelve inches (12"), and the top side of the box shall be between finished grade and six inches (6") below grade.

e. Handholes shall not be installed on steep banks or slopes where the cover can not be leveled with a tolerance of one inch (1") of drop to twelve inches (12") of grade.

f. Handholes shall be placed at all splice locations. Handholes may be ordered at other locations directed by Contractor or shown on the Drawings.

g. Manholes shall be installed in the same manner as handholes with the following exceptions:

- Subcontractor shall not use material less than five thousand $(5,000)$ pounds per square inch (psi) in density to shim frames and covers.

- Frames and covers shall be installed to match existing grade and shall be shimmed with either steel or concrete spacers.

- Manholes shall be installed to provide the proper manhole lid elevation and shall be set level and plumb. A six inch (6") pad of coarse aggregate shall be placed to obtain a level subgrade prior to manhole placement.

- All joints between precast concrete elements shall be sealed with sealant material in accordance with the manufacturer's specifications.

- Grade adjustment of the manhole frame and lid of three inches (3") and over shall be accomplished with precast concrete grade rings. Adjustments less than three inches (3") shall be made with nonshrink grout.

h. Manholes with frame, locking lid, riser casting, and grade rings shall be placed to provide a final finish grade elevation as follows:

- Roadway Concrete or Asphalt Pavement: The frame and lid shall be placed flush with the existing or proposed finish pavement grade to prevent a rough or uneven driving surface. Final pavement placement shall be flush with the top of the manhole frame. 
- Off-Roadway Concrete or Asphalt Pavement: The frame and lid shall be placed two inches (2") higher than the existing or proposed finish grade to prevent surface run-off water from entering. Final pavement placement shall be flush with the top of the manhole frame by tapering the pavement to the finish grading in all directions from the manhole frame, as required by governing authorities or ROW owners. Manhole frame shall be set level.

- Residential Lawns: The frame and lid shall be placed two inches (2") higher than the existing finish grade to prevent surface run-off water from entering the manhole. Final sodding or topsoil for seeding shall be placed to the top of the manhole frame and graded to taper the lawn areas to the existing contour and provide drainage in all directions from the manhole frame. Manhole frames shall normally be set level, but may be set unleveled to match the existing grade as required by governing authorities or ROW owners.

- Undeveloped or Rural Areas: The frame and lid shall be placed two inches (2") higher than the existing finish grade to prevent surface run-off water from entering the manhole. Final soil grading shall be to the top of the manhole frame and tapered to existing contour to provide drainage in all directions from the manhole frame. Manhole frames shall be set level or as required by governing authorities or ROW owners.

i. Subcontractor shall install manhole and handhole hardware in accordance with the manhole and handhole fabricator's specifications and drawings. All hardware shall be installed prior to cable placing.

4. Installing Pipe into Manholes.

a. The steel casing pipe shall be encased in concrete around and underneath the handhole.

b. Manhole openings shall be enlarged, if necessary, by drilling to accept the diameter of pipe being installed. A core type bit shall be used to make the opening. The finished diameter of the enlarged opening shall not exceed the outside diameter of the pipe by more than one-half inch $(1 / 2 ")$. Care shall be taken not to damage pipe at manhole connections during the placement of backfill material.

5. Installation of Ducts in Handholes. The arrangement of colored ducts exiting a handhole shall be the same as their entrance.

\section{MARKER PLACEMENT}

1. Description. This section covers the installation of FOC System markers with warning and information signs identifying the cable route. 


\section{Material Requirements.}

a. Marker poles, cable route signs, special markers, and mounting hardware shall be furnished as specified in the Drawings.

b. Requirements of each individual marker for appropriate signs shall be as indicated on the Drawings. Signs shall be nine inches (9") by twelve inches (12") by 0.05 inches aluminum baked enamel (alloy \# 5052H38) warning sign. Signs shall be custom printed, black on orange, dual sided with ultra violet clear coat with radius corners. Signs shall be furnished with two (2) prepunched holes to match holes provided on the steel posts having a spacing of one inch (1") on center.

c. All mounting hardware shall be hot-dip galvanized. Nails shall be hotdip galvanized barbed deck nails. Rivets shall be aluminum with a 7/8" to 1-1/8" grip range part number BALM-8BP-18.

d. Cable warning signs shall be installed on eight foot (8') long steel posts as shown on the Drawings. Steel posts shall have a white polyester powder coating and weigh approximately 1.12 pounds per foot.

e. Warning signs shall be stamped with individual numbers and shown on the Redline Drawings.

3. Installation.

a. All markers shall be installed as indicated on the Drawings and as follows:

- $\quad$ One (1) side of each bore and bridge attachment handhole location.

b. The cable marker posts shall be placed whenever possible with a one foot $\left(1^{\prime}\right)$ offset from the Network running line.

c. Posts shall be plumb, with signs level and correctly positioned. Markers shall be set concurrently with other FOC System work. Markers shall be set prior to installation of the cable.

d. Driven posts shall be held in alignment while being driven. The post top shall be protected during driving by means of a cap or other accepted device to prevent damage. All damaged posts shall be removed and replaced at no additional cost to the Contractor. Posts shall be driven to a depth of thirty-six inches (36"), unless rock or other subsurface obstacles occur, in which case the post may be installed a minimum of eighteen inches (18") with a concrete slurry backfill of six inches (6") around the post.

e. Warning signs shall be installed at the time the post is set. 
f. Warning sign posts shall not be installed within fifteen feet (15') of the levee toes.

\section{RIGHT-OF-WAY RESTORATION AND PROTECTION - RESTORATION AND REVEGETATION}

1. Description. Subcontractor shall furnish all work, including labor, equipment, supplies, materials (unless otherwise specified), and supervision to furnish and install ROW restoration and vegetation as required and or specified by the permits and or the rules and regulations of the governing authority or ROW owner and Contractor. Subcontractor shall furnish and install ROW restoration and revegetation, including, but not limited to, clean-up, repair, protection, and revegetation of the ROW work area after installation of the Conduit System. Restoration shall begin within forty-eight (48) hours following duct installation and be completed as soon as practicable as determined by the Contractor or the requirements of permits, governing authorities or ROW owners.

2. All disturbed areas shall be revegetated. Seeding shall be in accordance with State Department of Transportation specifications.

3. Permanent or temporary (silt fence) fence posts shall not be installed within fifteen feet (15') of the levee toes.

4. After removal of temporary silt fence, backfill anchor trench in accordance with Article 9(c) and (d).

\section{REPORTING}

1. The Contractor shall notify Mr. Pat Conroy seven (7) days before the work described in this Special Condition is to begin.

2. The Contractor shall furnish two (2) copies of pertinent As-Built Drawings, including, but not limited to, all laboratory and field testing reports, plan/profiles and drill stem external pressure report to:

St. Louis District, Corps of Engineers

1222 Spruce Street

St. Louis, MO 63103-2833

Attn: CEMVS-ED-GF

Patrick J. Conroy, P.E. 


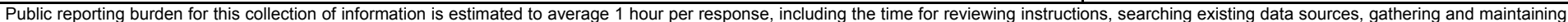

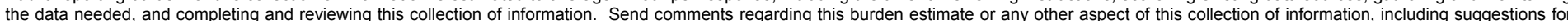

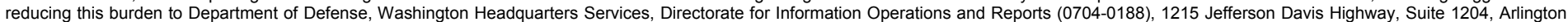

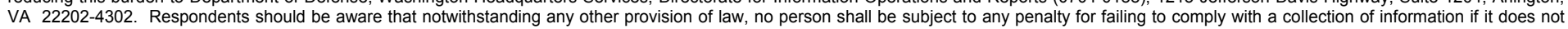
display a currently valid OMB control number. PLEASE DO NOT RETURN YOUR FORM TO THE ABOVE ADDRESS.

\begin{tabular}{l|c}
$\begin{array}{l}\text { 1. REPORT DATE (DD-MM-YYYY) } \\
\text { May } 2002\end{array}$ & $\begin{array}{c}\text { 2. REPORT TYPE } \\
\text { Final report }\end{array}$ \\
\hline
\end{tabular}

\section{TITLE AND SUBTITLE}

Installation of Fiber-Optic Cables Under Flood-Protection Structures Using Horizontal Directional Drilling Techniques

3. DATES COVERED (From - To)

5a. CONTRACT NUMBER

5b. GRANT NUMBER

5c. PROGRAM ELEMENT NUMBER

5d. PROJECT NUMBER

5e. TASK NUMBER

5f. WORK UNIT NUMBER

8. PERFORMING ORGANIZATION REPORT NUMBER

ERDC/GSL TR-02-8

Development Center

Geotechnical and Structures Laboratory

3909 Halls Ferry Road

Vicksburg, MS 39180-6199

\section{SPONSORING / MONITORING AGENCY NAME(S) AND ADDRESS(ES)}

10. SPONSOR/MONITOR'S ACRONYM(S)

Headquarters, U.S. Army Corps of Engineers

Washington, DC 20314-1000

11. SPONSOR/MONITOR'S REPORT NUMBER(S)

\section{DISTRIBUTION / AVAILABILITY STATEMENT}

Approved for public release; distribution is unlimited.

\section{SUPPLEMENTARY NOTES}

\section{ABSTRACT}

Increased use of communications cables has increased the frequency of requests to install cables and other utilities under flood-control levees. The U.S. Army Corps of Engineers, specifically the U.S. Army Engineer District, St. Louis (CEMVS), has allowed the use of horizontal directional drilling (HDD) for cable installation beneath levees along the Mississippi, Meramec, and Wood Rivers.

Installations were successful because of careful assessment of subsurface geotechnical conditions prior to initiating field activities, careful specifications, and monitoring of fluid pressures and other critical parameters throughout field operations. This report describes the process of planning, installing, and monitoring HDD under levees at two projects for CEMVS. Utility installations of this type can be completed without damage to the levee in appropriate geologic settings as long as the operation is conducted in a manner that does not fracture the levee blanket or topstratum. Key parameters in the St. Louis experience, in addition to geologic setting and monitoring of fluid pressures, included set-back distance on the landward side of the levee for initiating the drilling, and drilling beneath the levee and river at a depth adequate to contain the drilling operation in bedrock.

\begin{tabular}{|c|c|c|c|c|c|}
\hline \multicolumn{2}{|l|}{$\begin{array}{l}\text { 15. SUBJECT TERMS } \\
\text { Annular space } \\
\text { Directional drilling }\end{array}$} & $\begin{array}{l}\text { Fiber-optic cab } \\
\text { Geotechnical e } \\
\text { Hydrofracture }\end{array}$ & $\begin{array}{l}\text { es } \\
\text { gineering }\end{array}$ & \multicolumn{2}{|c|}{ Residual pressure } \\
\hline \multicolumn{3}{|c|}{ 16. SECURITY CLASSIFICATION OF: } & $\begin{array}{l}\text { 17. LIMITATION } \\
\text { OF ABSTRACT }\end{array}$ & $\begin{array}{l}\text { 18. NUMBER } \\
\text { OF PAGES }\end{array}$ & $\begin{array}{l}\text { 19a. NAME OF RESPONSIBLE } \\
\text { PERSON }\end{array}$ \\
\hline $\begin{array}{l}\text { a. REPORT } \\
\text { UNCLASSIFIED }\end{array}$ & $\begin{array}{l}\text { b. ABSTRACT } \\
\text { UNCLASSIFIED }\end{array}$ & $\begin{array}{l}\text { c. THIS PAGE } \\
\text { UNCLASSIFIED }\end{array}$ & & 72 & $\begin{array}{l}\text { 19b. TELEPHONE NUMBER (include } \\
\text { area code) }\end{array}$ \\
\hline
\end{tabular}

